\author{
G. E. Khaikina ${ }^{1,2}$, S. F. Solodovnikov ${ }^{3,4}$, \\ O. M. Basovich ${ }^{1}$, Z. A. Solodovnikova ${ }^{3}$, \\ Y. M. Kadyrova ${ }^{1}$, A. A. Savina ${ }^{1,2}$, E. S. Zolotova ${ }^{3}$, \\ V. N. Yudin ${ }^{3,4}$, T. S. Spiridonova ${ }^{1,2}$ \\ ${ }^{1}$ FSBUN Baikal Institute \\ of nature management $S B R A S$, \\ 670047, Ulan-Ude, Sakhyanovoy str., 6 \\ ${ }^{2}$ FSBGU HPE "Buryat state University", \\ 670000, Ulan-Ude, Smolina str., 24a \\ ${ }^{3}$ Institute of inorganic chemistry \\ Sibiryan Branch RAS, \\ 630090, Novosibirsk, prospect Akademika \\ Lavrentyeva, 3 \\ ${ }^{4}$ Federal state Autonomous educational institution \\ "Novosibirsk national research \\ state University”, 630090, Novosibirsk, Pirogov str., 2 \\ egkha@mail.ru,solod@niic.nsc.ru
}

\title{
Triple molybdates one-, one - and three(two)valence metals
}

the review summarizes experimental data on the phase formation, structure and properties of new complex oxide compounds group - triple molybdates containing tetrahedral molybdate ion, two different singly charged cation, together with tri- or divalent cation. The several structural families of these compounds were distinguished and it shown that many of them are of interest as luminescent, laser, ion-conducting or nonlinear optical materials.

Keywords: triple molybdates, one-, two - and trivalent metals, phase formation, structure, functional
properties.

The authors thank Ph. D. M. K. Alibaeva, Ph. D. I. A. Gudkova and Ph. D. I. V. Korolkova for participation in the research.

The work is executed at partial support of the Russian Foundation for basic research (projects No. 08-0300384, 13-03-01020 and 14-03-00298).

(C) Khaikina G. E., Solodovnikov S. F., Basovich 0. M., Solodovnikova Z. A., Kadyrova Y. M., Savina A. A., Zolotova E. S., Yudin V. N., Spiridonova T. S., 2015

The molybdates and tungstates are among the most popular objects of inorganic chemistry, crystal chemistry and solid state chemistry, as well as a base for developing of functional materials for various purposes, which maintains a constant interest in these compounds and explains a significant number of publications on this subject. 
In 1960-80 the focus of the scientists was double molybdates and tungstates phases with the general formula $A_{x} B_{y}\left(\mathrm{XO}_{4}\right)_{z}$, on the basis of which laser, ferroelectric, scintillation, nonlinear optical and other materials were later developed [1-5]. The main contribution to the formation of this group of compounds and their comprehensive study was made of the Russian scientific school: professor Kovba L. M., professor Trunov V. K. (Moscow state University named M. V. Lomonosov), professor Zhukovsky V. M, professor Tkachenko E. V. (Ural state University named A. M. Gorky, Sverdlovsk), corresponding member of Academy of Sciences of USSR Mokhosoev M. V. (Donetsk state University; Buryat Institute of natural Sciences, Sibiriyan Brunch of Academy of Sciences USSR, Ulan-Ude), professor Mayer A. A (Moscow chemical-technological Institute named D. I. Mendeleev), professor Golub A. M. (Kiev state University), candidate of physico-mathematical sciences Klevtsova P. V., candidate of physico-mathematical sciences Klevtsova R. F. (Institute of in- organic chemistry of Sibiriyan Brunch of Academy of Sciences USSR, Novosibirsk) and etc.

In the last two decades there has been a shifting of the centre gravity of studies from double molybdates and tungstates on triple molybdates. To date, this group of compounds has more than 550 individuals and is the fastest growing of complex oxide phases containing tetrahedral anion and cation. The large part of triple molybdates is prepared and is characterized by the employees of the Baikal Institute of nature management SB RAS (Ulan-Ude) and the Institute of inorganic chemistry named A. V. Nikolaev SB RAS (Novosibirsk). A brief overview of the different types of triple molybdates, different combinations of the charges of their constituent cations is earlier presented in [6]. The aim of this work is a detailed consideration of the phase formation, structure and properties of triple molybdates, containing two different singly mono-charged cation along with triple-charged (type 1-1-3) or doubly charged (type 1-1-2) cation.

\section{Triple molybdates of the type 1-1-3}

The first systematic searching researches of triple molybdates of one-, one-, and trivalent metals were conducted for lithium-containing systems $\mathrm{Li}_{2} \mathrm{MoO}_{4}-$ $M_{2} \mathrm{MoO}_{4}-R_{2}\left(\mathrm{MoO}_{4}\right)_{3}(M=\mathrm{K}-\mathrm{Cs}, \mathrm{Tl}, \mathrm{Ag}$, $R=\mathrm{Bi}, \mathrm{Ln}, \mathrm{Y}, \mathrm{In}, \mathrm{Sc}, \mathrm{Fe}, \mathrm{Ga}, \mathrm{Cr}, \mathrm{Al})$. Their result was the identification, synthesis and characterization of about 40 compounds of compositions $\mathrm{LiMR} 2\left(\mathrm{MoO}_{4}\right)_{4}$, $\mathrm{Li}_{2} R\left(\mathrm{MoO}_{4}\right)_{3}, \quad \quad \mathrm{Li}_{2} \mathrm{M}_{3} R\left(\mathrm{MoO}_{4}\right)_{4}$, $\mathrm{LiM}_{4} R\left(\mathrm{MoO}_{4}\right)_{4}, \mathrm{Li}_{2} M R\left(\mathrm{MoO}_{4}\right)_{3}$ which initiated the formation of an extensive group of triple molybdates of the type 1-1-3. The typical variants of systems triangula- tion in which these phases are formed are represented in Fig. 1. The belonging of the considered compounds to eight structural types is set, for representatives of five of whom crystals were obtained and the crystal structures are determined

Triple molybdates of the most numerous isostructural series of compounds of the composition $\mathrm{LiMR}_{2}\left(\mathrm{MoO}_{4}\right)_{4}$ are formed with the bismuth and lanthanides on some quasi-binary sections of $\mathrm{LiR}\left(\mathrm{MoO}_{4}\right)_{2}-\mathrm{MR}\left(\mathrm{MoO}_{4}\right)_{2}$ of systems $\mathrm{Li}_{2} \mathrm{MoO}_{4}-M_{2} \mathrm{MoO}_{4}-R_{2}\left(\mathrm{MoO}_{4}\right)_{3}(M=\mathrm{K}$, $\mathrm{Rb}, \mathrm{Tl})$. The domains of existence of these 
phases in a series of REE vary significantly and with increasing size of singly charged cations move in the direction to the light lanthanides (Fig. 2).

The analysis of experimental data allows to draw a conclusion about the decisive influence of dimensional factor on the possibility of the formation of monoclinic triple molybdates of this family: $\operatorname{LiMLn}\left(\mathrm{MoO}_{4}\right)_{4}$ are formed, if the difference in sizes of ions of large singly charged cation and rare earth element lies in the interval. $0.48 \AA \dot{A} \leq r\left(M^{+}\right)-r\left(L n^{3+}\right) \leq$ 0.60 Á.

At lower values of $\Delta r$ in the cut of $\mathrm{Li} \operatorname{Ln}\left(\mathrm{MoO}_{4}\right)_{2}-M \operatorname{Ln}\left(\mathrm{MoO}_{4}\right)_{2}$ there is the formation of solid solutions. When $\Delta r>$ $0.60 \AA$ the consider phase is either not formed or its formation is so complicated that the connection cannot be allocated in single-phase condition using conventional methods of solid-phase synthesis [11].

Within the prescribed time interval the isothermally and isostructural copper compounds $\mathrm{CuKLn}\left(\mathrm{MoO}_{4}\right)_{4}$ with Gd, Tb, Ho are prepared and characterized in [12, 13] are stacked. The closeness of $r\left(\mathrm{Cu}^{+}\right)$ and $r\left(\mathrm{Li}^{+}\right)$with a high degree of probability allows to predict a significant expansion of the triple molybdates $M^{\prime} M^{\prime \prime} R_{2}\left(\mathrm{MoO}_{4}\right)_{4}$ due to containing $\mathrm{Cu}(\mathrm{I})$ phases of this type with $\mathrm{K}, \mathrm{Tl}, \mathrm{Rb}$, and those of trivalent elements, the difference in dimensions which will satisfy the proposed criterion.

The structure of triple molybdates $\mathrm{LiMR}\left(\mathrm{MoO}_{4}\right)_{4}$ is defined by the exam-
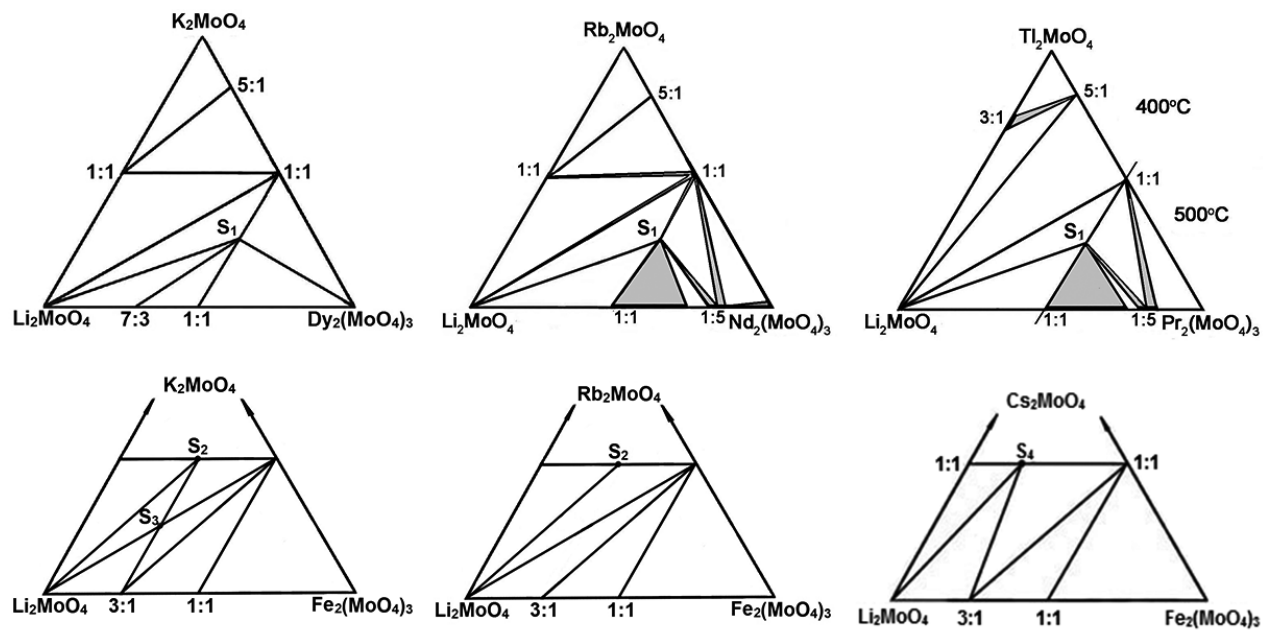

Fig. 1. Subsolidus structure of some systems $\mathrm{Li}_{2} \mathrm{MoO}_{4}-\mathrm{M}_{2} \mathrm{MoO}_{4}-R_{2}\left(\mathrm{MoO}_{4}\right)_{3}$ [7-10]: $S_{1}$ $-\mathrm{LiMR} R_{2}\left(\mathrm{MoO}_{4}\right)_{4} ; S_{2}-\mathrm{Li} M_{2} R\left(\mathrm{MoO}_{4}\right)_{3} ; S_{3}-\mathrm{Li}_{2} M R\left(\mathrm{MoO}_{4}\right)_{3} ; S_{4}-\mathrm{Li}_{2} M_{3} R\left(\mathrm{MoO}_{4}\right)_{4}$. Region $\mathrm{LiMMoO}-\mathrm{M}_{2} \mathrm{MoO}_{4}-M \mathrm{Fe}\left(\mathrm{MoO}_{4}\right)_{2}$ систем $\mathrm{Li}_{2} \mathrm{MoO}_{4}-M_{2} \mathrm{MoO}_{4}-\mathrm{Fe}_{2}\left(\mathrm{MoO}_{4}\right)_{3}(M=\mathrm{K}, \mathrm{Rb}, \mathrm{Cs})$ is not a quasi-threefold.

\begin{tabular}{c|c|c|c|c|c}
\hline $\boldsymbol{L n}$ & $\mathrm{La}$ & $\mathrm{Ce}, \mathrm{Pr}$ & $\mathrm{Nd}$ & $\mathrm{Sm}, \mathrm{Eu}$ & Gd-Lu, Y \\
\hline $\mathrm{K}$ & & & & & \\
\hline $\mathrm{Tl}$ & & & & & \\
\hline $\mathrm{Rb}$ & & & & &
\end{tabular}

Fig. 2. The domains of existence of triple molybdates $\operatorname{LiML} n_{2}\left(\mathrm{MoO}_{4}\right)_{4}$ (shaded) 
ple $\mathrm{LiRbBi}_{2}\left(\mathrm{MoO}_{4}\right)_{4}$, the only compound of this family which congruently melting [14]. Other compounds $\operatorname{LiMR}\left(\mathrm{MoO}_{4}\right)_{4}$ decompose in the solid phase at the corresponding double molybdates [7, 15] and their structure (for example $\left.\mathrm{Li} M \mathrm{Nd}_{2}\left(\mathrm{MoO}_{4}\right)_{4}, M=\mathrm{K}, \mathrm{Tl}, \mathrm{Rb}\right)$ was refined by the Rietveld method for powder data [16]. The structures $\operatorname{LiMR} R_{2}\left(\mathrm{MoO}_{4}\right)_{4}$ are close to the structure of triple molybdates $\mathrm{Li}_{3} \mathrm{Ba}_{2} \mathrm{Ln}_{3}\left(\mathrm{MoO}_{4}\right)_{8} \quad$ [17] and are derived from the structural type $\mathrm{BaNd}_{2}\left(\mathrm{MoO}_{4}\right)_{4}$ [18]. A characteristic features of structures $\mathrm{Li} M R_{2}\left(\mathrm{MoO}_{4}\right)_{4}$ are the laced layers of the $R \mathrm{O}_{8}$ polyhedron and connected to them through common vertices $\mathrm{MoO}_{4}$-tetrahedra. The neighbouring layers are interconnected by octahedra and $\mathrm{LiO}_{6}$ polyhedra $\mathrm{MO} 10$ (Fig. 3).

The presence in compounds $\mathrm{Li} M R_{2}\left(\mathrm{MoO}_{4}\right)_{4}$ ions $\mathrm{Li}^{+}$, filling the interstitial voids of the structural type $\mathrm{BaNd}_{2}\left(\mathrm{MoO}_{4}\right)_{4}$ suggests that they have lithium ionic conductivity. The results $[19,20]$ indicate the possibility of using these triple molybdates as sensitive elements of sensors of sensor systems for operational environmental monitoring. Spectral-luminescent characteristics $\mathrm{LiMLn}\left(\mathrm{MoO}_{4}\right)_{4}: \mathrm{Eu}^{3+}\left(\mathrm{Nd}^{3+}\right)$ give the basis to speak about the possibility of the application of triple molybdates of this family to create luminophors with high contrast colors, as well as active media of lasers [8, 21]. The data obtained in [22] show the availability of using $\operatorname{LiKGd}_{2}\left(\mathrm{MoO}_{4}\right)_{4}$ : in the capacity of: $\mathrm{Eu}^{3+}$ is as a red phosphor for WLED.

As in the previous case, the possibility of formation of other isostructural series of triple molybdates $\mathrm{Li}_{2} M_{3} R\left(\mathrm{MoO}_{4}\right)_{4}(M R$ $=\mathrm{CsFe}, \mathrm{CsGa}, \mathrm{RbGa}, \mathrm{CsAl}, \mathrm{RbAl}, \mathrm{TlAl})$ is largely determined by a dimensional fac- tor: compounds are formed by small cations $\mathrm{Fe}^{3+}, \mathrm{Ga}^{3+}, \mathrm{Al}^{3+}$ with tetrahedral coordination and quite major ions $\mathrm{Tl}^{+}, \mathrm{Rb}^{+}$ and $\mathrm{Cs}^{+}$. The absence $\mathrm{Li}_{2} \mathrm{M}_{3} \mathrm{Cr}\left(\mathrm{MoO}_{4}\right)_{4}$ is apparently due to the high preference of $\mathrm{Cr}^{3+}$ in octahedral coordination. These tetragonal compounds have a frame structure and are ordered derivatives of the cubic $\mathrm{Cs}_{6} \mathrm{Zn}_{5}\left(\mathrm{MoO}_{4}\right)_{8}[23,24]$. With the increasing of size of $R^{3+}$, the region of existence of these phases shifts towards larger singly charged cations $M^{+}$, which can be explained by the compliance of the sizes of the tetrahedral framework and the size of the extra framework cation. Obviously with namely dimensional discrepancy the crystallization $\mathrm{Li}_{2} \mathrm{~K}_{3} \mathrm{Al}\left(\mathrm{MoO}_{4}\right)_{4}$ is bound in a different structural type [10].

It is shown that $\mathrm{LiK}_{2} \operatorname{In}\left(\mathrm{MoO}_{4}\right)_{3}$, $\mathrm{LiRb}_{2} \mathrm{Fe}\left(\mathrm{MoO}_{4}\right)_{3}, \quad \mathrm{LiCs}_{4} \mathrm{Al}\left(\mathrm{MoO}_{4}\right)_{4}$ and $\mathrm{LiCs}_{4} \mathrm{Al}\left(\mathrm{MoO}_{4}\right)_{4}$ form new structural types that have not other members (table 1). Get fit for x-ray crystallographic

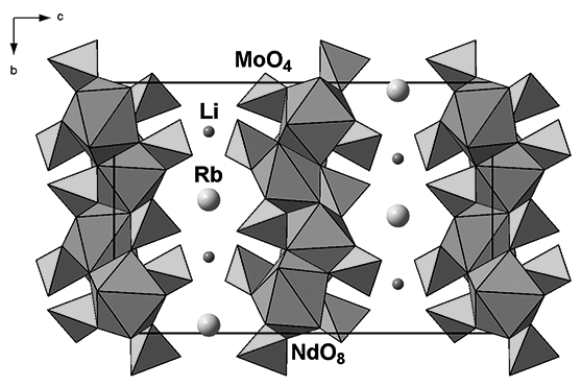

Fig. 3. Projection patterns $\mathrm{LiRbNd}_{2}\left(\mathrm{MoO}_{4}\right)_{4}$ along the axis $a$

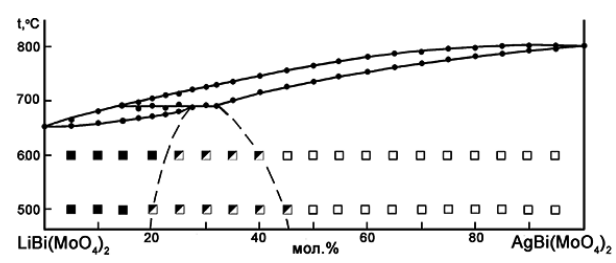

Fig. 4. T-x-diagram of a cut $\mathrm{LiBi}\left(\mathrm{MoO}_{4}\right)_{2}-\mathrm{AgBi}\left(\mathrm{MoO}_{4}\right)_{2}[29]$ 
studies single crystals of $\mathrm{LiK}_{2} \mathrm{Fe}\left(\mathrm{MoO}_{4}\right)_{3}$, $\mathrm{Li}_{2} \mathrm{KFe}\left(\mathrm{MoO}_{4}\right)_{3}$ and $\mathrm{Li}_{2} \mathrm{~K}_{3} \mathrm{Al}\left(\mathrm{MoO}_{4}\right)_{4}$ or to find structural prototypes of these compounds have not yet succeeded.

In none of the systems $\mathrm{Li}_{2} \mathrm{MoO}_{4}-\mathrm{Ag}_{2}$ $\mathrm{MoO}_{4}-R_{2}\left(\mathrm{MoO}_{4}\right)_{3}$ triple molybdates are not found [28-30]. The incisions $\mathrm{Li} R\left(\mathrm{MoO}_{4}\right)_{2}-\mathrm{Ag} R\left(\mathrm{MoO}_{4}\right)_{2}$ in the bismuth- and lanthanoid-containing systems are characterized by the formation of extended boundary solid solutions (Fig. 4).

Made in recent years the researches of systems $M_{2} \mathrm{MoO}_{4}-\mathrm{Cs}_{2} \mathrm{MoO}_{4}-R_{2}\left(\mathrm{MoO}_{4}\right)_{3}$ ( $M=\mathrm{Na}, \mathrm{Ag}$ ) allowed significantly to fill the group of triple molybdates of one-, one- and trivalent metals due to the sodium and silver-containing phases. The compositions and the fields of the existence of thus obtained compounds are shown in table. 2, the data of the RSA of the obtained single crystals are presented in table. 3 .

Studied sodium compounds have, as a rule, difficult structures and frame struc- tures (Fig. 5, 6), different in structure from the triple molybdates formed in the systems $\mathrm{Li}_{2} \mathrm{MoO}_{4}-M_{2} \mathrm{MoO}_{4}-R_{2}\left(\mathrm{MoO}_{4}\right)_{3} \quad(M$ $=\mathrm{K}-\mathrm{Cs}, \mathrm{Tl})$. In the structures of the sodium-containing triple molybdates $\mathrm{MoO}_{4}$ tetrahedra and $\mathrm{RO}_{6}$-octahedra are present and sodium has an octahedral or trigonalprismatic coordination or generates polyhedra with lower $\mathrm{CN}$. In these structures the $\mathrm{Na}^{+}$and $\mathrm{R}^{3+}$ quite often jointly occupy one crystallographic position; along with them there are positions which partially filled with sodium cations that leads to the deviation of composition from stoichiometry. The phases of variable composition are widely distributed among the complex (double and triple) sodium molybdates $[33,34]$, due to the proximity of sizes of ions $\mathrm{Na}^{+}$and и $A^{2+}$ or $\mathrm{R}^{3+}$.

According to the data of RSA, all triple molybdates found in the systems $\mathrm{Ag}_{2}$ $\mathrm{MoO}_{4}-\mathrm{Cs}_{2} \mathrm{MoO}_{4}-R_{2}\left(\mathrm{MoO}_{4}\right)_{3}$ are isoformular to sodium analogs and are built on the same structural basis [32].

Table 1

Data RSA single crystals $\mathrm{LiK}_{2} \mathrm{In}\left(\mathrm{MoO}_{4}\right)_{3}, \mathrm{LiRb}_{2} \mathrm{Fe}\left(\mathrm{MoO}_{4}\right)_{3}$ and $\mathrm{LiCs}_{4} \mathrm{Al}\left(\mathrm{MoO}_{4}\right)_{4}$ [25-27]

\begin{tabular}{c|c|c|c|c|c|c} 
Compound & Pr. gr.; $\mathrm{Z}$ & $a, \AA$ & $b, \AA$ & $c, \AA$ & $\beta, \circ$ & $R, \%$ \\
\hline $\mathrm{LiK}_{2} \mathrm{In}\left(\mathrm{MoO}_{4}\right)_{3}$ & $P 2_{1} ; 2$ & $7.0087(2)$ & $9.2269(3)$ & $10.1289(3)$ & $107.401(1)$ & 22.80 \\
\hline $\mathrm{LiRb}_{2} \mathrm{Fe}\left(\mathrm{MoO}_{4}\right)_{3}$ & $P n m a ; 4$ & $24.3956(6)$ & $5.8306(1)$ & $8.4368(2)$ & - & 2.11 \\
\hline $\mathrm{LiCs}_{4} \mathrm{Al}\left(\mathrm{MoO}_{4}\right)_{4}$ & $P 2 ; 2$ & $15.940(3)$ & $8.266(2)$ & $8.319(2)$ & $105.13(3)$ & 2.85
\end{tabular}

Table 2

Triple molybdates in systems $\mathrm{M}_{2} \mathrm{MoO}_{4}-\mathrm{Cs}_{2} \mathrm{MoO}_{4}-R_{2}\left(\mathrm{MoO}_{4}\right)_{3}$ $(M=\mathrm{Na}, R=\mathrm{Bi}, L n$, In, Sc, Fe; $M=\mathrm{Ag}, R=\mathrm{Bi}, L n, \mathrm{In}, \mathrm{Sc})[31,32]$

\begin{tabular}{|c|c|c|c|c|c|c|c|c|c|c|c|c|c|}
\hline & \multicolumn{7}{|c|}{$M=\mathrm{Na}$} & \multirow{2}{*}{ Phase } & \multicolumn{5}{|c|}{$M=\mathbf{A g}$} \\
\hline & $\mathrm{Bi}$ & Tm & $\mathrm{Yb}$ & Lu & In & Sc & $\mathrm{Fe}$ & & $\mathrm{Bi}$ & $\mathrm{Yb}$ & Lu & In & Sc \\
\hline$S_{1}$ & * & * & & & & & & $M_{13-3 x} \mathrm{Cs}_{11} R_{2+r}\left(\mathrm{MoO}_{4}\right)_{15}$ & & & & & \\
\hline $\mathrm{S}_{2}$ & & & * & & & & & $M_{5} \mathrm{Cs}_{7} R_{2}\left(\mathrm{MoO}_{4}\right)_{9}$ & & & & & \\
\hline$S_{3}$ & * & & & & & & & $M C s_{2} R\left(\mathrm{MoO}_{4}\right)_{3}$ & 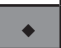 & & & & \\
\hline$S_{4}$ & & & & & $\begin{array}{l}{ }^{{ } \mathrm{B} / \mathrm{T}} \\
\mathbf{H} / \mathrm{T}\end{array}$ & & & $M_{3} \mathrm{Cs}_{3} R_{2}\left(\mathrm{MoO}_{4}\right)_{6}$ & & & & & \\
\hline$S_{5}$ & & & & & * & * & * & $M_{25} \mathrm{Cs}_{8} R_{5}\left(\mathrm{MoO}_{4}\right)_{24}$ & & & & & \\
\hline
\end{tabular}

fields of compounds, based on common structural basis, equally shaded

* - the resulting crystals and structure was determined on single crystal data by method RSA;

- - the resulting crystals and settings of cells were determined on single crystal data. 
Data RSA of single crystals of triple molybdates of

Table 3

sodium, cesium and trivalent metals [31]

\begin{tabular}{|c|c|c|c|c|}
\hline & Compound & Pr. gr.; $Z$ & Lattice parameters & $R$ \\
\hline \multirow[b]{2}{*}{$S_{1}$} & $\mathrm{Na}_{723} \mathrm{Cs}_{11} \mathrm{Tm}_{392}\left(\mathrm{MoO}_{4}\right)_{15}$ & $\mathrm{~Pb}_{3} / \mathrm{mcm} ; 2$ & $a=10.5849(1), c=37.4867(6) \AA$ & 0.029 \\
\hline & $\mathrm{Na}_{772} \mathrm{Cs}_{11} \mathrm{Bi}_{376}\left(\mathrm{MoO}_{4}\right)_{15}$ & $\mathrm{~Pb}_{3} / \mathrm{mcm} ; 2$ & $a=10.5507(1), c=37.6640(1) \AA$ & 0.038 \\
\hline $\mathrm{S}_{2}$ & $\mathrm{Na}_{5} \mathrm{Cs}_{7} \mathrm{Yb}_{2}\left(\mathrm{MoO}_{4}\right)_{9}$ & $R 32 ; 3$ & $a=10.5107(2), c=36.358(7) \AA$ & 0.035 \\
\hline$S_{3}$ & $\mathrm{NaCs}_{2} \mathrm{Bi}\left(\mathrm{MoO}_{4}\right)_{3}$ & $R 3 c ; 12$ & $a=10.6435(2), c=40.9524(7) \AA$ & 0.020 \\
\hline$S_{4}$ & $\mathrm{~B} / \mathrm{T}-\mathrm{Na}_{3} \mathrm{Cs}_{3} \mathrm{In}_{2}\left(\mathrm{MoO}_{4}\right)_{6}$ & $R \overline{\mathbf{3}} ; 12$ & $a=17.5753(2), c=29.4333(3) \AA$ & 0.032 \\
\hline \multirow{3}{*}{$S_{5}$} & $\mathrm{Na}_{25} \mathrm{Cs}_{8} \mathrm{In}_{5}\left(\mathrm{MoO}_{4}\right)_{24}$ & $P 2_{1} / c ; 4$ & $\begin{array}{c}a=12.6392(2), b=21.4601(4) \\
c=14.0313(3) \AA, \beta=90.017(1)^{\circ}\end{array}$ & 0.030 \\
\hline & $\mathrm{Na}_{25} \mathrm{Cs}_{8} \mathrm{Sc}_{5}\left(\mathrm{MoO}_{4}\right)_{24}$ & $P 2_{1} 2_{1} 2_{1} ; 2$ & $\begin{array}{c}a=28.6452(6), b=14.0043(3) \\
c=12.6482(2) \AA\end{array}$ & 0.072 \\
\hline & $\mathrm{Na}_{25} \mathrm{Cs}_{8} \mathrm{Fe}_{5}\left(\mathrm{MoO}_{4}\right)_{24}$ & $P \overline{1} ; 2$ & $\begin{array}{c}a=12.5814(5), b=13.8989(5) \\
c=28.4386(9) \AA, \alpha=90.108(2) \\
\beta=90.064(2), \gamma=90.020(2)^{\circ}\end{array}$ & 0.044 \\
\hline
\end{tabular}

In practical terms, triple molybdates $\mathrm{Na}_{25} \mathrm{Cs}_{8} R_{5}\left(\mathrm{MoO}_{4}\right)_{24}$ are the most interesting which the closely related structures are solved by single crystal data in the framework of pr. gr. $P 2_{1} / c$ (In), $P 22_{1} 2_{1}$ (Sc), $P \overline{1}(\mathrm{Fe})[38,39]$. The Mo atoms in all three structures are coordinated tetrahedral, trivalent metal is octahedral, all or some of them occupy their positions together with the atoms of sodium. The remaining $\mathrm{Na}$ atoms have rather distorted oxygen coordination ( $\mathrm{CN}=5$ and 6$)$; the atoms of cesium are $\mathrm{CN}=9-10$ (In), 11 (Sc), 10-12 (Fe); some positions of the sodium cations may be partially settled. In all structures it is possible to allocate polyhedral layers which formed by pairs of articulated along edges of the octahedra $(R, \mathrm{Na}) \mathrm{O}_{6}$ and $(R, \mathrm{Na}) \mathrm{O}_{6}\left(\right.$ or $\left.R \mathrm{O}_{6}\right)$ that are connected by vertices with bridging $\mathrm{MoO}_{4}$-tetrahedra (Fig. 6, $a-c$ ). The layers contact bridging $\mathrm{MoO}_{4}$-tetrahedra in the
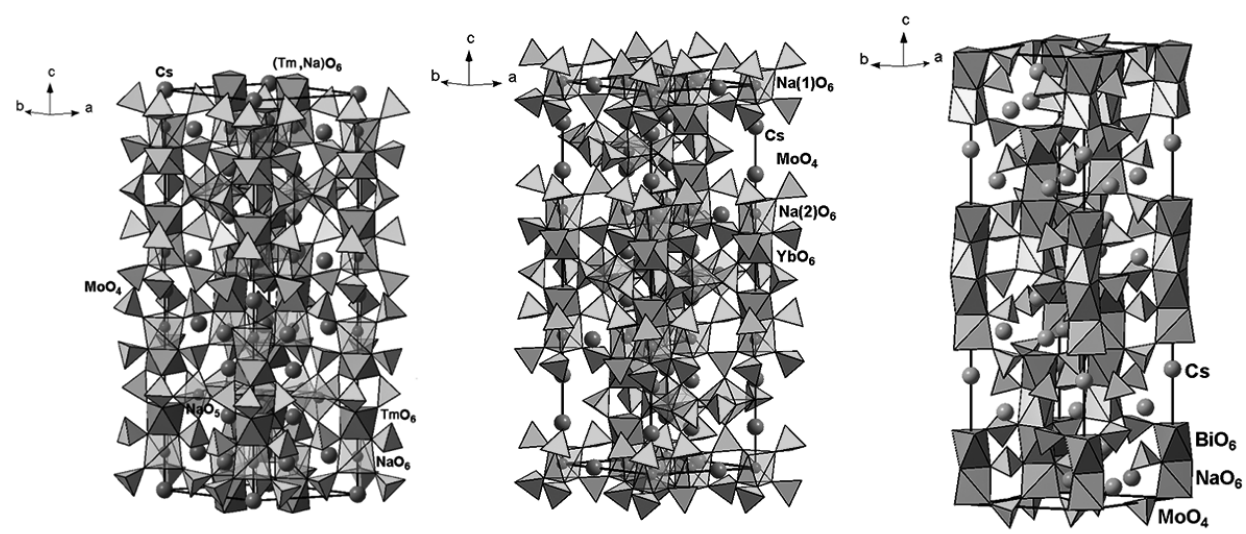

Fig. 5. Structures $\mathrm{Na}_{7.23} \mathrm{Cs}_{11} \mathrm{Tm}_{3.92}\left(\mathrm{MoO}_{4}\right)_{15}(a), \mathrm{Na}_{5} \mathrm{Cs}_{7} \mathrm{Yb}_{2}\left(\mathrm{MoO}_{4}\right)_{9}(b)$, $\mathrm{NaCs}_{2} \mathrm{Bi}\left(\mathrm{MoO}_{4}\right)_{3}(\mathrm{c})$ [35-37] 

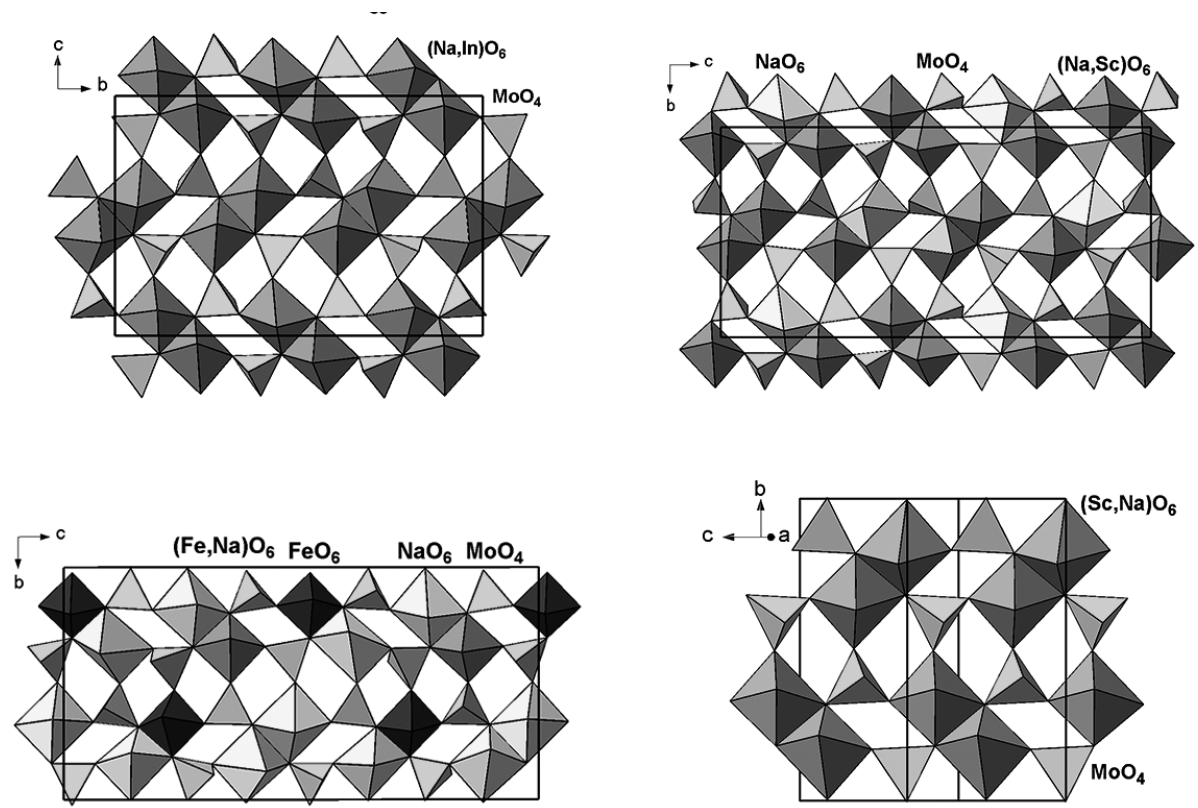

Fig. 6. Polyhedral fragments (layers) in the structures $\mathrm{Na}_{25} \mathrm{Cs}_{8} \mathrm{In}_{5}\left(\mathrm{MoO}_{4}\right)_{24}(a)$, $\mathrm{Na}_{25} \mathrm{Cs}_{8} \mathrm{Sc}_{5}\left(\mathrm{MoO}_{4}\right)_{24}(b), \mathrm{Na}_{25} \mathrm{Cs}_{8} \mathrm{Fe}_{5}\left(\mathrm{MoO}_{4}\right)_{24}(c), \mathrm{Na}_{5} \mathrm{Sc}\left(\mathrm{MoO}_{4}\right)_{4}(d)$ [38]

three-dimensional skeleton the voids of which are cations $\mathrm{Cs}^{+}$and $\mathrm{Na}^{+}$. In all cases the structure of the layers goes back to the polyhedral layer of patterns $\mathrm{Na}_{5} \mathrm{Sc}\left(\mathrm{MoO}_{4}\right)_{4}$ (Fig. 6, d), related to the type alluaudite $(\mathrm{Na}, \mathrm{Ca})(\mathrm{Fe}, \mathrm{Mn}, \mathrm{Mg})_{3}\left(\mathrm{PO}_{4}\right)_{3}$ [40]. The rhombic or pseudorhombic metric of cells of triple molybdates occurs due to some mutual shift of the layers in comparison with monoclinic $\mathrm{Na}_{5} \mathrm{Sc}\left(\mathrm{MoO}_{4}\right)_{4}$ and alluaudite (pr. gr. $\mathrm{C} 2 / \mathrm{c}$ ), which may be due to the presence of cesium cations between the layers. Structural features of this group of triple molybdates suggests that this is not the kind of structural type of alluaudite and a separate, let closely related structural family.

The study of alluaudite-like ion-conductive properties of triple molybdates showed that these compounds undergo reversible phase transitions of type I, fol- lowed by an abrupt increase of conductivity. Above the temperatures of phase transitions, the electrical conductivity reaches values of $10^{-2}-10^{-3} \mathrm{sm} / \mathrm{Sm}$, which gives an opportunity to consider $\mathrm{Na}_{25} \mathrm{Cs}_{8} R_{5}\left(\mathrm{MoO}_{4}\right)_{24}(R=\mathrm{In}, \mathrm{Sc}, \mathrm{Fe})$ as the promising objects for the development of new materials with high ionic conductivity $[38,39]$.

The structural features of the other described above triple molybdates also allow to expect the existence of them increased the sodium (silver)-ionic conductivity and improve their conductive characteristics that apparently it is possible to achieve by suitable heterovalent substitutions with replacing part of the sodium (silver) or other cation in the structure on more high strength field and education vacancies. 


\section{Triple molybdates of type 1-1-2}

Among triple salt systems $\mathrm{M}_{2} \mathrm{MoO}_{4}$ $M{ }_{2}{ }_{2} \mathrm{MoO}_{4}-\mathrm{AMoO}_{4}$ to date, the most studied systems are that consist of lithium molybdate, heavy alkali elements ( $\mathrm{K}, \mathrm{Rb}, \mathrm{Cs}$ ) and $\mathrm{Mg}, \mathrm{Mn}, \mathrm{Co}, \mathrm{Ni}, \mathrm{Co}, \mathrm{Zn}, \mathrm{Cd}, \mathrm{Ca}, \mathrm{Sr}, \mathrm{Ba}$, $\mathrm{Pb}$. Most of these systems are not phaseforming, the solid solutions are formed in some of them on the basis of double molybdates. One triple molybdate was found in the six systems; their characteristics are presented in table. 4 .

In the triple systems $\mathrm{Li}_{2} \mathrm{MoO}_{4}-$ $\mathrm{K}_{2} \mathrm{MoO}_{4}-\mathrm{AMoO}_{4}(\mathrm{~A}=\mathrm{Mg}, \mathrm{Mn}, \mathrm{Co})$ in quasi-binary sections $\mathrm{Li}_{2} A_{2}\left(\mathrm{MoO}_{4}\right)_{3}-$ $\mathrm{K}_{2} A_{2}\left(\mathrm{MoO}_{4}\right)_{3}$ (Fig. 7) the rhombohedral triple molybdates $\mathrm{K}_{3+x} \mathrm{Li}_{1-x} A_{4}\left(\mathrm{MoO}_{4}\right)_{6}$ $(0 \leq x \leq 0.3)$ are revealed $[42,43]$. They crystallized in the structural type II$\mathrm{Na}_{3} \mathrm{Fe}_{2}\left(\mathrm{AsO}_{4}\right)_{3}$ [49], in which the cations are distributed as follows: $\left(\mathrm{Na}_{5} \square\right)^{\mathrm{IX}}(\mathrm{Ml})$ ${ }^{\mathrm{VI}}(M 2)^{\mathrm{VI}}(M 3)_{3}{ }^{\mathrm{VI}}\left(\mathrm{AsO}_{4}\right)_{6}=\left(\mathrm{Na}_{5} \square\right)(\mathrm{Na})$ $\left(\mathrm{Fe}^{3+}\right)\left(\mathrm{Fe}^{3+}\right)_{3}\left(\mathrm{AsO}_{4}\right)_{6}$ (here the Roman numerals denote the $\mathrm{CN}$ of the cations in the positions M1, M2 and M3). In the structures of the triple molybdates cations $\mathrm{Li}$, $A^{2+}$ and $\mathrm{K}^{+}$are placed at the positions $\mathrm{M} 1$, M2 and M3 (Fig. 8), and the main part of the potassium is in a position with $\mathrm{CN}=9$, busy half due to short contacts $\mathrm{C}-\mathrm{C}$. The presence of potassium in the same position with the cations $\mathrm{Mg}^{2+}, \mathrm{Mn}^{2+}, \mathrm{Co}^{2+}, \mathrm{Li}^{+}$ is rare case for crystal chemistry. Found on the structural data the compositions of the crystals are confirmed by good convergence of the local balance of valence efforts. The basis of all structures are three dimensional frames from octahedra around M1, M2 and M3 and tetrahedra

Table 4

Crystallographic and thermal properties of triple molybdates of the type 1-1-2 [41-48]

\begin{tabular}{|c|c|c|c|c|c|c|}
\hline \multirow{2}{*}{ Compound } & \multirow{2}{*}{ Pr. gr.; Z } & \multicolumn{4}{|c|}{ The unit cell parameters } & \multirow{2}{*}{$\begin{array}{c}\mathrm{T}_{\text {melt' }} \\
{ }^{\circ} \mathrm{C}\end{array}$} \\
\hline & & $a, \AA$ & $b, \AA$ & $c, \AA$ & $\beta,{ }^{\circ}$ & \\
\hline $\mathrm{K}_{3.11} \mathrm{Li}_{0.89} \mathrm{Mg}_{4}\left(\mathrm{MoO}_{4}\right)_{6}$ & $R \overline{3} c ; 6$ & $14.3541(2)$ & - & $19.7338(4)$ & - & $730^{*}$ \\
\hline $\mathrm{K}_{3.07} \mathrm{Li}_{0.93} \mathrm{Mn}_{4}\left(\mathrm{MoO}_{4}\right)_{6}$ & $R \overline{3} c ; 6$ & $14.5896(3)$ & - & $19.9773(8)$ & - & 720 \\
\hline $\mathrm{K}_{3.14} \mathrm{Li}_{0.86} \mathrm{Mn}_{4}\left(\mathrm{MoO}_{4}\right)_{6}$ & $R \overline{3} c ; 6$ & $14.607(2)$ & - & $19.992(4)$ & - & - \\
\hline $\mathrm{K}_{330} \mathrm{Li}_{070} \mathrm{Co}_{4}\left(\mathrm{MoO}_{4}\right)_{6}$ & $R \overline{3} c ; 6$ & $14.4391(3)$ & - & 19.891(1) & - & $710^{*}$ \\
\hline $\mathrm{K}_{3} \mathrm{NaNi}_{4}\left(\mathrm{MoO}_{4}\right)_{6}$ & $R \overline{3} c ; 6$ & $14.2790(2)$ & - & $19.7589(4)$ & - & 750 \\
\hline $\mathrm{K}_{3} \mathrm{NaMg}_{4}\left(\mathrm{MoO}_{4}\right)_{6}$ & $R \overline{3} c ; 6$ & $14.4528(2)$ & - & $19.8894(3)$ & - & 720 \\
\hline $\mathrm{K}_{3} \mathrm{NaCo}_{4}\left(\mathrm{MoO}_{4}\right)_{6}$ & $R \overline{3} c ; 6$ & $14.4638(1)$ & - & $19.8369(3)$ & - & $530^{*}$ \\
\hline $\mathrm{Rb}_{3} \mathrm{LiZn}_{2}\left(\mathrm{MoO}_{4}\right)_{4}$ & $I \overline{4} 3 d ; 4$ & $11.902(1)$ & - & - & - & 580 \\
\hline $\mathrm{Cs}_{3} \mathrm{LiCo}_{2}\left(\mathrm{MoO}_{4}\right)_{4}$ & $I \overline{4} 3 d ; 4$ & $12.2239(2)$ & - & - & - & $740 \%$ \\
\hline $\mathrm{Cs}_{3} \mathrm{LiZn}_{2}\left(\mathrm{MoO}_{4}\right)_{4}$ & $I \overline{4} 3 d ; 4$ & $12.2100(1)$ & - & - & - & 690 \\
\hline $\mathrm{Cs}_{3} \mathrm{NaZn}_{2}\left(\mathrm{MoO}_{4}\right)_{4}$ & $I \overline{4} 3 d ; 4$ & $12.3134(1)$ & - & - & - & 510 \\
\hline $\mathrm{Cs}_{3} \mathrm{AgZn}_{2}\left(\mathrm{MoO}_{4}\right)_{4}$ & $I \overline{4} 3 d ; 4$ & $12.3049(2)$ & - & - & - & 530 \\
\hline $\mathrm{CsNa}_{5} \mathrm{Mn}_{3}\left(\mathrm{MoO}_{4}\right)_{6}$ & $C 2 / c ; 2$ & $13.3659(3)$ & $13.6897(3)$ & $7.1692(2)$ & $112.727(1)$ & 701 \\
\hline $\mathrm{Cs}_{4} \mathrm{Na}_{10} \mathrm{Mn}_{5}\left(\mathrm{MoO}_{4}\right)_{12}$ & $P 2 / c ; 4$ & $13.8597(3)$ & $12.5719(2)$ & $28.4209(3)$ & $90.097(1)$ & 576 \\
\hline $\mathrm{CsNa}_{5} \mathrm{Co}_{3}\left(\mathrm{MoO}_{4}\right)_{6}$ & $\mathrm{C} 2 / c ; 2$ & $13.0917(8)$ & $13.5443(8)$ & $7.1217(4)$ & $112.331(2)$ & 615 \\
\hline $\mathrm{Cs}_{4} \mathrm{Na}_{10} \mathrm{Co}_{5}\left(\mathrm{MoO}_{4}\right)_{12}$ & $\mathrm{Pbca} ; 4$ & $13.6572(3)$ & $12.5063(3)$ & $27.9898(5)$ & - & - \\
\hline $\mathrm{CsNa}_{5} \mathrm{Ni}_{3}\left(\mathrm{MoO}_{4}\right)_{6}$ & $C 2 / c ; 2$ & $13.212(3)$ & $12.458(3)$ & $7.120(1)$ & $112.245(3)$ & 636 \\
\hline
\end{tabular}




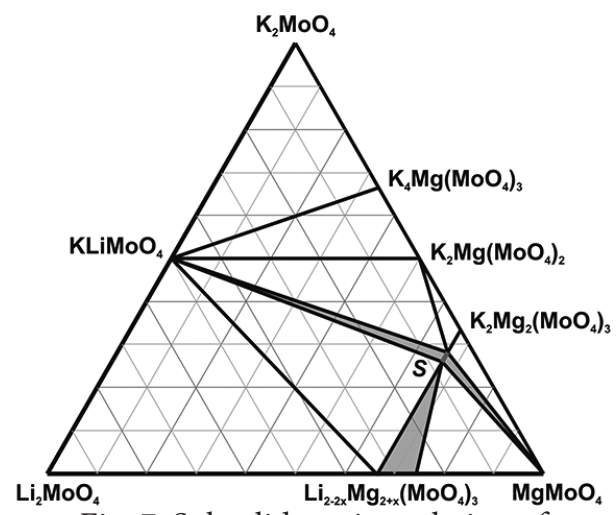

Fig. 7. Subsolidus triangulation of

$\mathrm{Li}_{2} \mathrm{MoO}_{4}-\mathrm{K}_{2} \mathrm{MoO}_{4}-\mathrm{MgMoO}_{4}$ at $550{ }^{\circ} \mathrm{C}$. S $\mathrm{K}_{3+x} \mathrm{Li}_{1-x} \mathrm{Mg}_{4}\left(\mathrm{MoO}_{4}\right)_{6}$

$\mathrm{MoO} 4$ in large extra-framework cavities there are potassium ions. In the systems $\mathrm{Na}_{2} \mathrm{MoO}_{4}-\mathrm{K}_{2} \mathrm{MoO}_{4}-A \mathrm{MoO}_{4}(A=\mathrm{Ni}, \mathrm{Mg}$, $\mathrm{Co})$ there are formed triple molybdates $\mathrm{K}_{3} \mathrm{NaA}_{4}\left(\mathrm{MoO}_{4}\right)_{6}$ similar in structure [44], figurative points are located on quasi-binary sections of $\mathrm{K}_{3} \mathrm{Na}\left(\mathrm{MoO}_{4}\right)_{2}-A \mathrm{MoO}_{4}$. In the structures of these compounds the positions M1, M2 and M3 are occupied by the cations $\mathrm{Na}^{+}, A^{2+}$ and $A^{2+}$, respectively, and the positions of potassium, as in the previous case are occupied only half. The data on these triple molybdates are given in table. 4. The isostructurality of considered triple molybdates to sodium-ion conductor II- $\mathrm{Na}_{3} \mathrm{Fe}_{2}\left(\mathrm{AsO}_{4}\right)_{3}$ gives reason to expect the presence of increased ionic conductivity. It is assumed that the ways of transport of ions in these phases are similar to found in the structure of II- $\mathrm{Na}_{3} \mathrm{Fe}_{2}\left(\mathrm{AsO}_{4}\right)_{3}$, where $\mathrm{Na}^{+}$cations are moved through the defective positions of sodium with $\mathrm{CN}=9$ and octahedral site $\mathrm{M} 1$, in the neighbouring coordination polyhedra and form three-dimensional network.

In the systems $\mathrm{Li}_{2} \mathrm{MoO}_{4}-\mathrm{Rb}_{2} \mathrm{MoO}_{4}-$ $A \mathrm{MoO}_{4}(A=\mathrm{Mg}, \mathrm{Mn}, \mathrm{Co}, \mathrm{Ni})$ and $\mathrm{Li}_{2}$

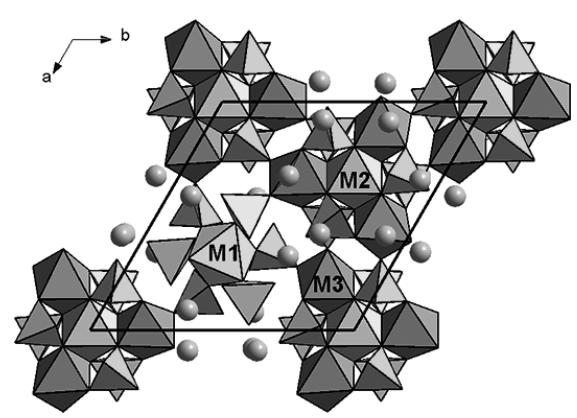

Fig. 8. The projection of the fragment of structure of triple molybdate

$\mathrm{K}_{3+x} \mathrm{Li}_{1-x} A_{4}\left(\mathrm{MoO}_{4}\right)_{6}(A=\mathrm{Mg}, \mathrm{Mn}, \mathrm{Co})$ on the plane (001).

$\mathrm{MoO}_{4}-\mathrm{Cs}_{2} \mathrm{MoO}_{4}-\mathrm{AMoO}_{4}(\mathrm{~A}=\mathrm{Mg}, \mathrm{Mn}$, $\mathrm{Ni}$ ) triple molybdates aren't formed. In systems with $\mathrm{Rb}$ and $\mathrm{Zn}$ (Fig. 9, a) and cesium-containing systems with Co and Zn (Fig. 9, b) $\mathrm{Rb}_{3} \mathrm{LiZn}_{2}\left(\mathrm{MoO}_{4}\right)_{4}$ и $\mathrm{Cs}_{3} \mathrm{Li}_{2}\left(\mathrm{MoO}_{4}\right)_{4}(A=\mathrm{Co}, \mathrm{Zn})$ are found [41-43], the isostructural cubic $\mathrm{Cs}_{6} \mathrm{Zn}_{5}\left(\mathrm{MoO}_{4}\right)_{8} \quad[23,24]$. The uniqueness of the composition and structure $\mathrm{Cs}_{6} \mathrm{Zn}_{5}\left(\mathrm{MoO}_{4}\right)_{8}$ is connected with the incompleteness of the tetrahedral positions of the zinc, where the sixth part is vacant. The filling of vacancies by ions $\mathrm{Li}^{+}$and other singly charged cations $\mathrm{M}^{+}$according to scheme $\mathrm{Zn}^{2+}+\square \rightarrow 2 M^{+}$creates the conditions for the synthesis of new compounds. An introduction to the structure of cubic $\mathrm{Cs}_{6} \mathrm{Zn}_{5}\left(\mathrm{MoO}_{4}\right)_{8}$ of singly charged cations $M^{+}=\mathrm{Na}, \mathrm{Ag}$ with close to $\mathrm{Zn}^{2+}$ ionic radius obtained cubic phases $\mathrm{Cs}_{3} \mathrm{MZn}_{2}\left(\mathrm{MoO}_{4}\right)_{4}$ with disordered distribution of cations $M^{+}$ on the positions of the $\mathrm{Zn}^{2+}$. The features $\mathrm{Cs}_{3} \mathrm{MZn}_{2}\left(\mathrm{MoO}_{4}\right)_{4}(M=\mathrm{Na}, \mathrm{Ag})$ are given in table. 4. According to our data $[43,50]$, between $\mathrm{Cs}_{3} \mathrm{MZn}_{2}\left(\mathrm{MoO}_{4}\right)_{4}(M=\mathrm{Li}, \mathrm{Na})$ and $\mathrm{Cs}_{6} \mathrm{Zn}_{5}\left(\mathrm{MoO}_{4}\right)_{8}$ there are continuous solid solutions (Fig. 9, b) with the gradual filling of the cationic vacancies in the 

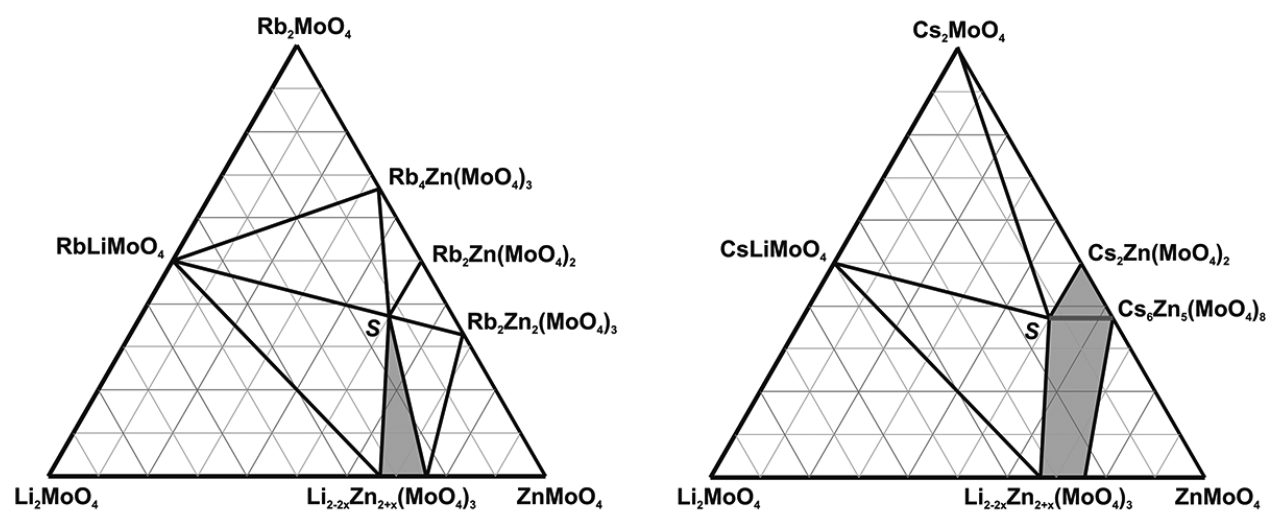

Fig. 9. Subsolidus triangulation of the triple systems at $510{ }^{\circ} \mathrm{C}: a-\mathrm{Li}_{2} \mathrm{MoO}_{4}-\mathrm{Rb}_{2} \mathrm{MoO}_{4}-$ $\mathrm{ZnMoO}_{4} ; b-\mathrm{Li}_{2} \mathrm{MoO}_{4}-\mathrm{Cs}_{2} \mathrm{MoO}_{4}-\mathrm{ZnMoO}_{4} \cdot S-M_{3} \mathrm{LiZn}_{2}\left(\mathrm{MoO}_{4}\right)_{4}(M=\mathrm{Rb}, \mathrm{Cs})$

structure $\mathrm{Cs}_{6} \mathrm{Zn}_{5}\left(\mathrm{MoO}_{4}\right)_{8}$. It is likely that a similar phenomenon occurs in the case of $\mathrm{Cs}_{3} \mathrm{AgZn}_{2}\left(\mathrm{MoO}_{4}\right)_{4}$. The formation of such solid solutions gives the opportunity within certain limits to control the composition, stability and properties of phases on the basis of $\mathrm{Cs}_{6} \mathrm{Zn}_{5}\left(\mathrm{MoO}_{4}\right)_{8}$.

It should be noted that the substitution and the simultaneous introduction into the position of zinc in the structure $\mathrm{Cs}_{6} \mathrm{Zn}_{5}\left(\mathrm{MoO}_{4}\right)_{8}$ different valent cations with very different ionic radius on the scheme $5 \mathrm{Zn}^{2+}+\square \rightarrow 2 R^{3+}+4 \mathrm{Li}^{+}$leads to the formation of the group of triple molybdates $\mathrm{Li}_{2} M_{3} R\left(\mathrm{MoO}_{4}\right)_{4}(M R=\mathrm{CsFe}$, CsGa, RbGa, CsAl, RbAl, TlAl) described above. In the latter case, the cations $\mathrm{Li}^{+}$ and $\mathrm{R}^{3+}$ are distributed orderly in structure, which leads to a tetragonal distortion of the structure of the prototype.

The basis of the structures of the triple molybdates of both series, as structures $\mathrm{Cs}_{6} \mathrm{Zn}_{5}\left(\mathrm{MoO}_{4}\right)_{8}$ are delicate three-dimensional frames. In phases with divalent metals they are formed by tetrahedrons of two sorts - around the molybdenum

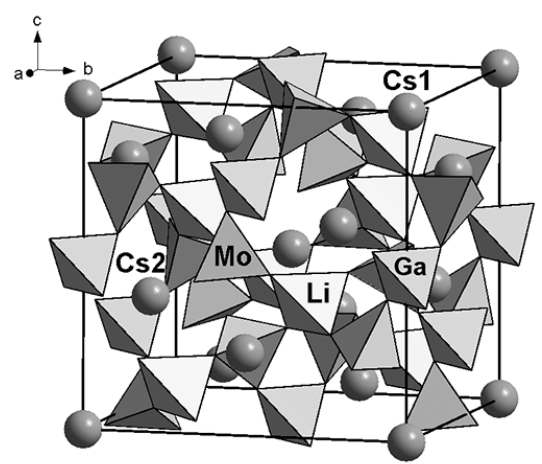

Fig. 10. The structure of triple molybdates derived from patterns $\mathrm{Cs}_{6} \mathrm{Zn}_{5}\left(\mathrm{MoO}_{4}\right)_{8}$ [23, 24]: $a$ - структура $\mathrm{LiCs}_{3} \mathrm{Co}_{2}\left(\mathrm{MoO}_{4}\right)_{4}$ (pr. gr. I $\overline{4} 3 d$ ) [41]; $b$ - структура $\mathrm{Li}_{2} \mathrm{Cs}_{3} \mathrm{Ga}\left(\mathrm{MoO}_{4}\right)_{4}$ (pr. gr. $I \overline{4} 2 d$ ) [42] 
and "mixed" position of lithium (sodium, silver) and a divalent cation; in the compounds with trivalent metals - tetrahedra $\mathrm{MoO}_{4}, \mathrm{LiO}_{4}$ and $\mathrm{RO}_{4}$. In large voids of the framework there are large singly charged cations with $\mathrm{CN}=12$ (Fig. 10).

All phases of family $\mathrm{Cs}_{6} \mathrm{Zn}_{5}\left(\mathrm{MoO}_{4}\right)_{8}$ have acentric structure and perspective to create materials for nonlinear optics. Moreover, an open frame structure leads to the manifestation of these compounds ion-conductive properties. The most significant results were obtained for $\mathrm{Rb}_{3} \mathrm{LiZn}_{2}\left(\mathrm{MoO}_{4}\right)_{4}$ and $\mathrm{Tl}_{3} \mathrm{Li}_{2} \mathrm{Al}\left(\mathrm{MoO}_{4}\right)_{4}$, the values of ionic conductivity (of the order of $2 \cdot 10^{-2} \mathrm{Sm} / \mathrm{sm}$ at 520 and $350{ }^{\circ} \mathrm{C}$, respectively), bring them closer to superionic conductors.

In the systems $\mathrm{Li}_{2} \mathrm{MoO}_{4}-\mathrm{M}_{2} \mathrm{MoO}_{4}-$ $A \mathrm{MoO}_{4}(M=\mathrm{Na}, \mathrm{K}, \mathrm{Rb}, \mathrm{Cs} ; A=\mathrm{Ca}$, $\mathrm{Sr}, \mathrm{Pb}, \mathrm{Ba}, \mathrm{Cd}$ ) triple molybdates aren't formed, however, there are areas of solid solutions (up to $15 \mathrm{~mol}$. \%) on the basis of double molybdates from faceting systems $\mathrm{M}_{2} \mathrm{MoO}_{4}-\mathrm{AMoO}_{4}$ [51].

In the study of solution-melt crystallization (solvent $-\mathrm{Cs}_{2} \mathrm{Mo}_{2} \mathrm{O}_{7}$ ) in the systems $\mathrm{Na}_{2} \mathrm{MoO}_{4}-\mathrm{Cs}_{2} \mathrm{MoO}_{4}-A \mathrm{MoO}_{4}(A=$ $\mathrm{Ni}, \mathrm{Co}, \mathrm{Mn})$ the crystals $\mathrm{CsNa}_{5} \mathrm{M}_{3}\left(\mathrm{MoO}_{4}\right)_{6}$
[47] related to the type alluaudite were isolated and structurally were investigated. The oxygen octahedra around the cations $A^{2+}$ and $\mathrm{Na}^{+}$are connected with common edges and faces, and then by common vertices with the $\mathrm{MoO}_{4}$ tetrahedra into a three-dimensional frame, which is parallel (100) is divided into two kinds of layers (Fig. 11). In one of these layers (Fig. 11) the wide channels filled with cesium ions pass parallel to the axis $c$, which occupy half their positions and have $\mathrm{CN}=8$. The comparison of eludicating structures $\mathrm{CsNa}_{5} A_{3}\left(\mathrm{MoO}_{4}\right)_{6}$ and $\mathrm{Na}_{4-2 x} A_{1+x}\left(\mathrm{MoO}_{4}\right)_{3}$ $(A=\mathrm{Ni}, \mathrm{Co}, \mathrm{Mn})$ shows that in the triple molybdates part of the cations $\mathrm{Na}^{+}$in the channels was replaced with $\mathrm{Cs}^{+}$, significantly increased the parameters of the cell along the axis $a$ and accordingly the width of the channels were significantly increased. View as along these channels the transport of sodium ions may be, it may increase the ionic conductivity. The close relationship of phases $\mathrm{CsNa}_{5} A_{3}\left(\mathrm{MoO}_{4}\right)_{6}$ and $\mathrm{Na}_{4-2 x} A_{1+x}\left(\mathrm{MoO}_{4}\right)_{3}(A=\mathrm{Ni}, \mathrm{Co}, \mathrm{Mn})$ can indicate the formation of solid solutions between them, which requires additional researches. The features $\mathrm{CsNa}_{5} A_{3}\left(\mathrm{MoO}_{4}\right)_{6}$ $(A=\mathrm{Ni}, \mathrm{Co}, \mathrm{Mn})$ are given in table. 4 .
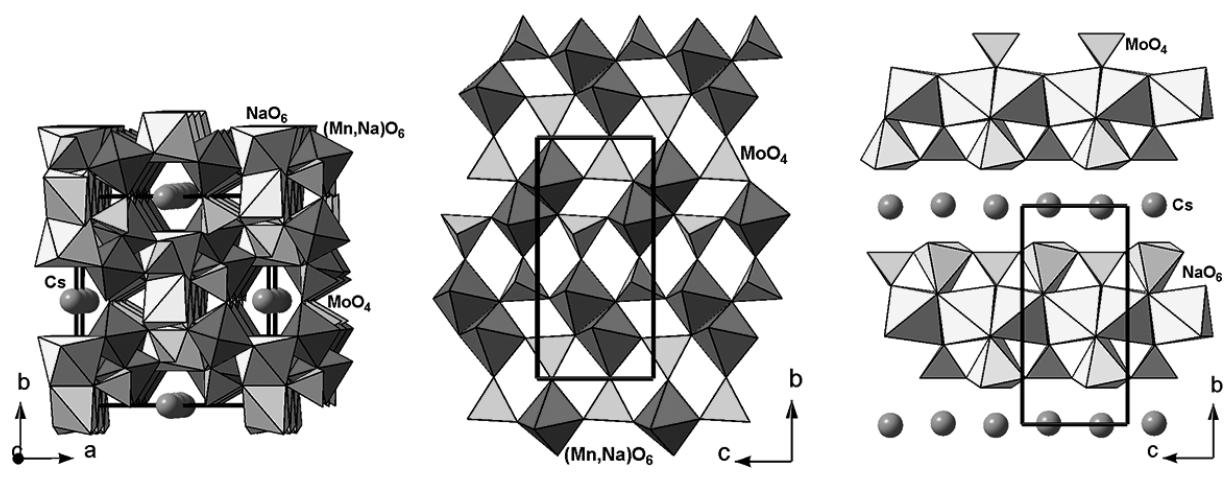

Fig. 11. Structure $\mathrm{CsNa}_{5} \mathrm{Mn}_{3}\left(\mathrm{MoO}_{4}\right)_{6}$ :

$a$ - general view; $b, c$ - two types of layers of polyhedra projected on (100) 
In the systems $\mathrm{Na}_{2} \mathrm{MoO}_{4}-\mathrm{Cs}_{2} \mathrm{MoO}_{4}-$ $A_{\mathrm{MoO}}(A=\mathrm{Co}, \mathrm{Mn})$ also highlighted the triple molybdates of composition $\mathrm{Cs}_{4} \mathrm{Na}_{10} A_{5}\left(\mathrm{MoO}_{4}\right)_{12}[46,48]$ (Fig. 12, table 4) also were highlighted, which were very similar in structure to the above compounds $\mathrm{Na}_{25} \mathrm{Cs}_{8} R_{5}\left(\mathrm{MoO}_{4}\right)_{24}(R=\mathrm{In}, \mathrm{Sc}$, $\mathrm{Fe}$ ), forming together with them obviously the single family of phases with similar metrics of cells and different symmetry. The structure $\mathrm{Cs}_{4} \mathrm{Na}_{10} \mathrm{Co}_{5}\left(\mathrm{MoO}_{4}\right)_{12}$ (pr. gr. $\mathrm{Pbca}$ ) is most symmetrical, which can be regarded as the ancestor of this family. The symmetry the other compounds may be raised at phase transitions, which must be accompanied by disordering of the structure and the possible increase in the mobility of sodium cations.

In this regard, we can expect high ionic conductivity at triple molybdates

\section{Concluding remarks}

Our carried studies of triple molybdates of the type 1-1-2 and 1-1-3 show that among them there are several families of isostructural or closely related in structure phases. The systems with trivalent metals have higher phase-forming ability, the large stoichiometric and structural diversity in which the triple molybdates belonging to 14 structural types (families) form, whereas triple molybdates of the type 1-1-2 belong only to four isostructural series. One from these explanations for this may be the wider range of cations $R^{3+}$ and their sizes compared to the ions $A^{2+}$ in the phase-forming systems $M_{2}{ }_{2} \mathrm{MoO}_{4}-M^{\prime \prime}{ }_{2} \mathrm{MoO}_{4}-A \mathrm{MoO}_{4}\left(M^{\prime}=\right.$ $\mathrm{Li}, \mathrm{Na} ; M^{\prime \prime}=\mathrm{K}, \mathrm{Rb}, \mathrm{Cs} ; A=\mathrm{Mg}, \mathrm{Mn}, \mathrm{Co}$, $\mathrm{Ni}, \mathrm{Zn})$. A number of identified families of triple molybdates of types 1-1-3 and 1-1-2 may be promising as functional materials. This is especially true of the fam-

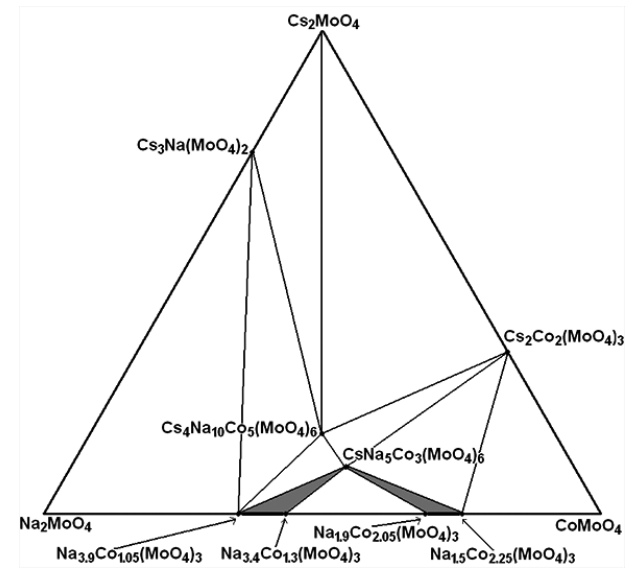

Fig. 12. Subsolidus triangulation of the $\mathrm{Na}_{2} \mathrm{MoO}_{4}-\mathrm{Cs}_{2} \mathrm{MoO}_{4}-\mathrm{CoMoO}_{4}$ at $480{ }^{\circ} \mathrm{C}$

$\mathrm{Cs}_{4} \mathrm{Na}_{10} A_{5}\left(\mathrm{MoO}_{4}\right)_{12}(A=\mathrm{Co}, \mathrm{Mn}$, as this is the case for $\mathrm{Na}_{25} \mathrm{Cs}_{8} R_{5}\left(\mathrm{MoO}_{4}\right)_{24}(R=\mathrm{In}$, $\mathrm{Sc}, \mathrm{Fe}$ ).

ily of compounds $\mathrm{LiMR}\left(\mathrm{MoO}_{4}\right)_{4}$ with interesting spectral-luminescent properties, as well as lithium- and sodiumcontaining triple molybdates of different structures, which may show an increased ion conductivity. Among the latest the compounds of families $\mathrm{Cs}_{6} \mathrm{Zn}_{5}\left(\mathrm{MoO}_{4}\right)_{8}$, II- $\mathrm{Na}_{3} \mathrm{Fe}_{2}\left(\mathrm{AsO}_{4}\right)_{3}$ and alluaudito-similar phase $\mathrm{Na}_{25} \mathrm{Cs}_{8} R_{5}\left(\mathrm{MoO}_{4}\right)_{24}(R=\mathrm{In}, \mathrm{Sc}, \mathrm{Fe})$ and $\mathrm{Cs}_{4} \mathrm{Na}_{10} M_{5}\left(\mathrm{MoO}_{4}\right)_{12}(M=\mathrm{Co}, \mathrm{Mn})$ for which the relevant researches have already conducted. From the crystallochemical point of view in this regard the compounds $\mathrm{LiMR}\left(\mathrm{MoO}_{4}\right)_{4}$ are also interesting, where the ions $\mathrm{Li}^{+}$fill internodic voids of structural type $\mathrm{BaNd}_{2}\left(\mathrm{MoO}_{4}\right)_{4}$ and the hexagonal or trigonal phases $S_{1}-S_{4}$ (table. 2, 3 ), in which the sodium ions have a nonstandard (trigonal-prismatic or lower) coordination that can contribute to ionic conductivity. Nonlinear optical properties 
can be expected from acentric triple molybdates $\mathrm{LiK}_{2} \mathrm{In}\left(\mathrm{MoO}_{4}\right)_{3}, \mathrm{LiCs}_{4} \mathrm{Al}\left(\mathrm{MoO}_{4}\right)_{4}$, $\mathrm{Na}_{5} \mathrm{Cs}_{7} \mathrm{Yb}_{2}\left(\mathrm{MoO}_{4}\right)_{9}, \mathrm{NaCs}_{2} \mathrm{Bi}\left(\mathrm{MoO}_{4}\right)_{3}$ and their analogues, as well as the phases of the family $\mathrm{Cs}_{6} \mathrm{Zn}_{5}\left(\mathrm{MoO}_{4}\right)_{8}$.

1. Trunov V. K., Efremov V. A., Velikodnyi Yu. A. Crystal chemistry and properties of double molybdates and tungstates. Leningrad: Nauka, 1986. 173 p.

2. Evdokimov A. A., Efremov V. A., Trunov V. K., Kleiman I. A., Tananaev I. V. Compounds of rare earth elements. The molybdates, tungstates. M.: Nauka, 1991. 267 p.

3. Kaminsky A. A., Aminov L. K., Ermolaev V. L., Kornienko A. A., Kravchenko E. B., Malkin B. Z., Mill' B. V., Perlin Yu. E., Petrosyan A. G., Pekhov K.K., Sakun V. P., Sarkisov S. E., Sveshnikova E. B., Skripko G. A., Starostin N. V. Shkadarevich A. P. Physics and spectroscopy of laser crystals. M.: Nauka, 1986. 272 p.

4. Isupov V. A. Binary molybdates and tungstates of mono- and trivalent elements as possible ferroelastics and ferroelectrics. Ferroelectrics. 2005;321:63-90. doi: $10.1080 / 00150190500259699$.

5. Usupov V. A. Ferroelectric and ferroelastic phase transitions in molybdates and tungstates of monovalent and bivalent elements. Ferroelectrics. 2005;322:83-114. doi: 10.1080/00150190500315574

6. Khaikina E. G., Bazarova Zh. G., Solodovnikov S. F., Klevtsova R. F. Triple molybdates as a basis for promising new complex oxide materials. Engineering environment. 2011;1:48-49.

7. Basovich O. M., Khaikina E. G., Solodovnikov S. F., Tsyrenova G. D. Phase formation in the systems $\mathrm{Li}_{2} \mathrm{MoO}_{4}-\mathrm{K}_{2} \mathrm{MoO}_{4}-\mathrm{Ln}_{2}\left(\mathrm{MoO}_{4}\right)_{3}(\mathrm{Ln}=\mathrm{La}, \mathrm{Nd}, \mathrm{Dy}, \mathrm{Er})$ and properties of triple molybdates $\operatorname{LiKLn}_{2}\left(\mathrm{MoO}_{4}\right)_{4}$. J. Solid State Chem. 2005;178(5):1580-1588. doi: 10.1016/j.jssc.2004.12.016.

8. Basovich O. M., Khaikina E.G., Vasilyev E. V., Frolov M. A. Phase formation in the systems $\mathrm{Li}_{2} \mathrm{MoO}_{4}-\mathrm{Rb}_{2} \mathrm{MoO}_{4}-\mathrm{Ln}_{2}\left(\mathrm{MoO}_{4}\right)_{3}$ and properties $\mathrm{LiRb} n_{2}\left(\mathrm{MoO}_{4}\right)_{4}$. J. Neorgan. chemistry. 1995;40(12):2047-2051.

9. Basovich O. M., Khaikina E. G. Phase equilibria in the system $\mathrm{Li}_{2} \mathrm{MoO}_{4}-\mathrm{Tl}_{2} \mathrm{MoO}_{4}-$ $\mathrm{Pr}_{2}\left(\mathrm{MoO}_{4}\right)_{3}$. J. Neorgan. chemistry. 2000;45(9):1542-1544.

10. Kadyrova M. Y. Phase formation, the synthesis and structure of new compounds in the systems $M_{2} \mathrm{MoO}_{4}-R_{2}\left(\mathrm{MoO}_{4}\right)_{3}$ and $\mathrm{Li}_{2} \mathrm{MoO}_{4}-M_{2} \mathrm{MoO}_{4}-R_{2}\left(\mathrm{MoO}_{4}\right)_{3}(M$ is an alkali metal; $R=\mathrm{In}, \mathrm{Sc}, \mathrm{Fe}, \mathrm{Ga}, \mathrm{Cr}, \mathrm{Al})$. Diss. Cand. chem. Sci., Ulan-Ude, 2010. 148 p.

11. Basovich O. M., Khaikina E. G. Regularities of formation helicopto-like triple molybdates $\operatorname{LiMLn}_{2}\left(\mathrm{MoO}_{4}\right)_{4}$. J. Neorg. Chem. 2006;51(7):1180-1184. doi: 10.1134/ S0036023606070114.

12. Szillat H., Müller-Buschbaum H. Synthese und Kristallstruktur von $\mathrm{KCuHoMo}_{4} \mathrm{O}_{16}$ Z. Naturforsch. 1994;49:350-354.

13. Müller-Buschbaum H., Gallinat St. Synthese und Röntgenstrukturanalyse von $\mathrm{KCuGd}_{2} \mathrm{Mo}_{4} \mathrm{O}_{16}$ und $\mathrm{KCuTb}_{2} \mathrm{Mo}_{4} \mathrm{O}_{16}$. Z. Naturforsch. 1995;50:1794-1798.

14. Klevtsova R. F., Glinskaya L. A., Alekseev V. I., Hal'baeva K. M., Khaikina E. G. Crystal-structural study of triple molybdates $\mathrm{LiRbBi}_{2}\left(\mathrm{MoO}_{4}\right)_{4}$. J. Struct. Chem. 1993;34(5):152-15. 
15. Hal'baeva K. M., Khaikina E. G. Subsolidus structure of the system $\mathrm{Li}_{2} \mathrm{MoO}_{4}-\mathrm{Tl}_{2}$ $\mathrm{MoO}_{4}-\mathrm{Bi}_{2}\left(\mathrm{MoO}_{4}\right)_{3}$. J. Neorgan. Chem. 2000;45(2):314-319.

16. Morozov V. A., Lazoryak B. I., Smirnov V. A., Mikhailin V. V., Basevich O. M., Khaikina E. G. Crystal structures and luminescence properties of triple molybdates $\mathrm{Li} M \mathrm{Nd}_{2}\left(\mathrm{MoO}_{4}\right)_{4}(M=\mathrm{K}, \mathrm{Rb}, \mathrm{Tl})$. J. Neorgan. Chem. 2001;46(6):977-982.

17. Klevtsova R. F., Vasilyev D. A., Glinskaya L. A., Kruglic A. I., Kozhevnikova N. M., Korsun V. P. Structure study of triple molybdates of composition $\mathrm{Li}_{3} \mathrm{Ba}_{2} \operatorname{Ln}_{3}\left(\mathrm{MoO}_{4}\right)_{8}$, Ln = Gd, Tm. J. Struct. Chem. 1992;33(3):126-130.

18. Kiseleva I. I., Sirota M. I., Ozerov R. I., Balakireva T. P., Mayer, A. A. Double molybdates of barium-lanthanide, , $\mathrm{BaLn}{ }_{2}\left(\mathrm{MoO}_{4}\right)_{4}$. Crystallography. 1979;24(6):1277-1279.

19. Bravina S., Morozovsky N., Pasechnik L., Khaikina E., Budnyk O. Characteristic behaviour of electric parameters of mesoporous materials under humidity impact. $9^{\text {th }}$ Eur. Conf. on Applications of Polar Dielectrics ECAPD-9. Abstract. Roma, Italy, 2008. Roma, 2008. P. 208.

20. Bravina S. L., Morozovsky N. V., Khaikina E. G., Boukherroub R., Dogheche E., Remiens D., Basovich O. M., Kadyrova Yu. M. Electrophysical study of fast humidity sensing of nano- and mesoporous media. Mater. Vseros. scientific. Conf. with the Intern. participation "Baikal materials science forum". 9-13 July 2012, Ulan-Ude. Ulan-Ude: Izd-vo BNTS SB RAS. 2012. Part 2. P. 23-25.

21. Yakovlev V. G., Mikhailin V. V., Romanenko A. Yu., Zaushizin A. V., Basovich O. M., Khaikina E. G. Spectral-luminescent properties of $\mathrm{LiRbLa}_{2-x} \mathrm{Eu}_{x}\left(\mathrm{MoO}_{4}\right)_{4}$. Vestnik MSU. Ser. 3. Physics. Astronomy. 2010;(5):56-59.

22. Xie A., Yuan X. M., Wang F. X. A potential red-emitting phosphors scheelite-like triple molybdates $\mathrm{LiKGd}_{2}\left(\mathrm{MoO}_{4}\right)_{4}: \mathrm{Eu}^{3+}$ for white light emitting diode applications. Sci. China. Tech. Sci. 2011;54(1):70-75. doi: 10.1007/s11431-010-4222-y.

23. Mueller M., Hildmann B. O., Hahn Th. Structure of $\mathrm{Cs}_{6} \mathrm{Zn}_{5}\left(\mathrm{MoO}_{4}\right)_{8}$. Acta crystallogr. 1987:C43(2):184-186.

24. Solodovnikov S. F., Klevtsov P. V., Glinskaya L. A., Klevtsova R. F. Synthesis and crystal structure of cesium-zinc molybdate $\mathrm{Cs}_{6} \mathrm{Zn}_{5}\left(\mathrm{MoO}_{4}\right)_{8}=2 \mathrm{Cs}_{3}\left(\mathrm{Zn}_{5 / 6} \square_{1 / 6}\right)_{3}\left(\mathrm{MoO}_{4}\right)_{4}$. Crystallography. 1987;32(3):618-622.

25. Khal'baeva K. M., Solodovnikov S. F., Khaikina E. G., Kadyrova Yu. M., Solodovnikova Z. A., Basovich O. M. Phase formation in the $\mathrm{Li}_{2} \mathrm{MoO}_{4}-\mathrm{K}_{2} \mathrm{MoO}_{4}-\mathrm{In}_{2}\left(\mathrm{MoO}_{4}\right)_{3}$ system and crystal structures of new compounds $\mathrm{K}_{3} \mathrm{InMo}_{4} \mathrm{O}_{15}$ and $\mathrm{LiK}_{2} \mathrm{In}\left(\mathrm{MoO}_{4}\right)_{3}$. J. Solid State Chem. 2012;87:276-281. doi: 10.1016/j.jssc.2012.01.010.

26. Khal'baeva K. M., Solodovnikov S. F., Khaikina E. G., Kadyrova Yu. M., Solodovnikova Z. A., Basovich O. M. Phase formation in the $\mathrm{Li}_{2} \mathrm{MoO}_{4}-\mathrm{Rb}_{2} \mathrm{MoO}_{4}-\mathrm{Fe}_{2}\left(\mathrm{MoO}_{4}\right)_{3}$ system and crystal structure of a novel triple molybdate $\mathrm{LiRb}_{2} \mathrm{Fe}\left(\mathrm{MoO}_{4}\right)_{3}$. J. Solid State Chem. 2013;203:227-231. doi: 10.1016/jjssc.2013.04.020.

27. Solodovnikov S. F., Solodovnikova Z. A., Kadyrova, Yu. M., Khaikina E. G., Basovich O. M. Phase formation in the system $\mathrm{Li}_{2} \mathrm{MoO}_{4}-\mathrm{Cs}_{2} \mathrm{MoO}_{4}-\mathrm{Al}_{2}\left(\mathrm{MoO}_{4}\right)_{3}$ and crystal structure $\mathrm{LiCs}_{4} \mathrm{Al}\left(\mathrm{MoO}_{4}\right)_{4}$. Mater. Vseros. scientific. Conf. with the Intern. participation "Baikal materials science forum". 9-13 July 2012, Ulan-Ude. Ulan-Ude: Izd-vo BNTS SB RAS, 2012. Part 2. P. 141-142. 
28. Haikina E. G., Basovich O. M., Hal'baeva K. M. Phase formation in silver-containing molybdate systems with the participation of trivalent metals. III all-Russian. scientific. Conf. physico-chemical analysis. Makhachkala, April 12-14, 2007, proc. Dokl. Makhachkala, 2007. S. 39-41.

29. Hal'baeva K. M., Khaikina E. G., Basovich O. M. Phase equilibria in molybdate systems of lithium-silver(sodium)-bismuth. J. Neorg. Chem. 2005;50(8):1380-1382.

30. Khaikina E. G. Synthesis, features of phase formation and structure of double and triple molybdates of one - and trivalent metals. Dis. Dr. chem. Sciences. Ulan-Ude, 2008. 446p.

31. Savina A. A. Synthesis, structure and properties of new compounds in the systems $\mathrm{Na}_{2} \mathrm{MoO}_{4}-\mathrm{Cs}_{2} \mathrm{MoO}_{4}-R_{2}\left(\mathrm{MoO}_{4}\right)_{3}(R-$ trivalent metal $)$. Dis. candidate. chem. Sciences. Ulan-Ude, 2013. 169 p.

32. Basovich O. M., Osokina A. N., Khaikina E. G., Solodovnikov S. F., Spiridonova T. S., Solodovnikova Z. A. Formation of phase in the systems $\mathrm{Ag}_{2} \mathrm{MoO}_{4}-\mathrm{Cs}_{2} \mathrm{MoO}_{4}-$ $R_{2}\left(\mathrm{MoO}_{4}\right)_{3}(R=\mathrm{Bi}, \mathrm{Nd}, \mathrm{Yb}, \mathrm{Lu}, \mathrm{In}, \mathrm{Sc})$. Proc. Dokl. School-conference of young scientists "Inorganic compounds and functional materials (ICFM-2015)". Novosibirsk: Publishing house of the Institute of inorganic chemistry SB RAS, 2015. P. 81.

33. Solodovnikov S. F. Peculiarities of phase formation and crystal chemistry of double molybdates and tungstates of the alkali and divalent metals and related phases. Dis. Dr. chem. Sciences. Novosibirsk: 2000. P. 424.

34. Kozhevnikova N. M., Mokhosoev M. V. Triple molybdates. Ulan-Ude: Publishing house of the Buryat state University, 2000. 297 p.

35. Uskova A. A., Basovich O. M., Solodovnikov S. F., Podkorytova Yu. O., Solodovnikova $Z$. A. The Search and study of triple molybdates of sodium with cesium and trivalent metals. Mater. Vseros. youth scientific and practical conference. with the Intern. participation «Resource-saving and environment-friendly technologies and materials». 12-14 may 2011, Ulan-Ude. Ulan-Ude: BSU, 2011. P. 57-59.

36. Basovich O. M., Uskova A. A., Solodovnikov S. F., Solodovnikova Z. A., Khaikina E. G. Formation of phase in the systems $\mathrm{Na}_{2} \mathrm{MoO}_{4}-\mathrm{Cs}_{2} \mathrm{MoO}_{4}-\mathrm{Ln}_{2}\left(\mathrm{MoO}_{4}\right)_{3}$ and crystal structure of new triple molybdate $\mathrm{Cs}_{7} \mathrm{Na}_{5} \mathrm{Yb}_{2}\left(\mathrm{MoO}_{4}\right)_{9}$. Bulletin of the Buryat state University. Vol. 3. Chemistry, physics. 2011;24-29.

37. Savina A. A., Atuchin V. V., Solodovnikov S. F., Solodovnikova Z. A., Krylov A. S., Maximovskiy E. A., Molokeev M. S., Oreshonkov A. S., Pugachev A. M., Khaikina E. G. Synthesis, structural and spectroscopic properties of acentric triple molybdate $\mathrm{Cs}_{2} \mathrm{NaBi}\left(\mathrm{MoO}_{4}\right)_{3}$. J. Solid State Chem. 2015;225:53-58. doi: 10.1016/j. jssc.2014.11.023.

38. Savina A. A., Solodovnikov S. F., Belov D. A., Basovich O. M., Solodovnikova Z. A., Gudkova I. A., Stefanovich S. Yu., Lazoryak B. I., Khaikina E. G. New ion-conducting triple molybdates with eludito-similar structure. "Environment-friendly and resource-saving technologies and materials». Mater. II Vseros. young. scientific. Conf. with the Intern. participation (Ulan-Ude, on May 15-16, 2014). Ulan-Ude: Publishing house of the Buryat state University, 2014. P. 93-94.

39. Savina A. A., Solodovnikov S. F., Belov D. A., Basovich O. M., Solodovnikova Z. A., 
Pokholok K. V., Stefanovich S. Yu., Lazoryak B. I., Khaikina E. G. Synthesis, crystal structure and properties of alluaudite-like triple molybdate $\mathrm{Na}_{25} \mathrm{Cs}_{8} \mathrm{Fe}_{5}\left(\mathrm{MoO}_{4}\right)_{24}$. J. Solid State Chem. 2014;220:217-220. doi: 10.1016/j.ssc.2014.09.004.

40. Moore P. B. Crystal chemistry of the alluaudite structure type: contribution to the paragenesis of pegmatite phosphate giant crystals. Amer. Miner. 1971;56(11-12):1955. 41. Solodovnikova Z. A., Solodovnikov S. F., Zolotova E. S. New triple molybdates $\mathrm{Cs}_{3} \mathrm{LiCo}_{2}\left(\mathrm{MoO}_{4}\right)_{4}$ and $\mathrm{Rb}_{3} \mathrm{LiZn}_{2}\left(\mathrm{MoO}_{4}\right)_{4}$, filled derivatives of the $\mathrm{Cs}_{6} \mathrm{Zn}_{5}\left(\mathrm{MoO}_{4}\right)_{8}$ type. Acta crystallogr. 2006;C62(1):i6-i8. doi: 10.1107/S0108270105037121.

42. Solodovnikov S. F., Khaikina E. G., Solodovnikova Z. A. Kadyrova Yu. M., Khal'baeva K. M., Zolotova E. S. New families of lithium-containing triple molybdates and stabilizing role of lithium in their structure. Reports of Russian Academy of Sciences. 2007; 416(1):60-65.

43. Solodovnikova Z. A. Phase formation and structure of triple molybdate and related compounds in the systems $\mathrm{Li}_{2} \mathrm{MoO}_{4}-A_{2}^{+} \mathrm{MoO}_{4}-M^{2+} \mathrm{MoO}_{4}\left(A^{+}=\mathrm{K}, \mathrm{Rb}, \mathrm{Cs} ; M^{2+}=\mathrm{Mg}\right.$, $\mathrm{Mn}, \mathrm{Co}, \mathrm{Ni}, \mathrm{Zn})$. Dis. candidate. chem. Sciences. Novosibirsk, 2008. 219p.

44. Solodovnikova Z. A., Solodovnikov S. F., Gudkova I. A., Zolotova E. S. Synthesis and structure of new triple molybdate $\mathrm{K}_{3} \mathrm{NaM}_{4}\left(\mathrm{MoO}_{4}\right)_{6}(M=\mathrm{Ni}, \mathrm{Mg}$, Co). Mater. Vseros. scientific. Conf. with the Intern. participation "Baikal materials science forum". 9-13 July 2012, Ulan-Ude. Ulan-Ude: Izd-vo bnts SB RAS, 2012. Part 2. P. 143-144.

45. Solodovnikov S. F., Solodovnikova Z. A., Zolotova E. S., Yudin V. N., Gudkova I. A., Kadyrova, Yu. M., Khaikina E. G., Triple molybdates (tungstates) of the family $\mathrm{Cs}_{6} \mathrm{Zn}_{5}\left(\mathrm{MoO}_{4}\right)_{8}$ TEZ Dokl. The 9th seminar of SB RAS - UrB RAS “Thermodynamics and material science"]. the memory of Acad. F. A. Kuznetsov. 30 June - 4 July 2014, Novosibirsk, Russia. Novosibirsk: Publishing house of the Institute of inorganic chemistry SB RAS, 2014. P. 108.

46. Yudin, V. N., Zolotova E. S., Solodovnikova Z. A., Solodovnikov S. F., Gudkova I. A. Formation of phase and structure of triple molybdate in the system $\mathrm{Cs}_{2} \mathrm{MoO}_{4}-$ $\mathrm{Na}_{2} \mathrm{MoO}_{4}-$. TEZ Dokl. The 9th seminar of SB RAS - UrB RAS “Thermodynamics and material science"]. the memory of Acad. F. A. Kuznetsov. 30 June - 4 July 2014, Novosibirsk, Russia. Novosibirsk: Publishing house of the Institute of inorganic chemistry SB RAS, 2014. P. 151.

47. Yudin V. N., Zolotova E. S., Shkerin S. N., Tolkacheva A. S., Uporov S. A., Solodovnikova Z. A., Solodovnikov S. F. Structure and properties of triple molybdates $\mathrm{CsNa}_{5} \mathrm{M}_{3}\left(\mathrm{MoO}_{4}\right)_{6}(M=\mathrm{Ni}, \mathrm{Co}, \mathrm{Mn}$. Mater. Vseros. scientific. Conf. with the Intern. "II Baikal materials science forum". 29 June - 5 July 2015, Ulan-Ude. UlanUde: Publishing house of Buryat scientific center SB RAS, 2015. Part 1. P. 146-148.

48. Yudin V. N., Zolotova E. S., Solodovnikova Z. A., Solodovnikov S. F., Tolkacheva A. S. Formation of phase, structure and properties of triple molybdates in the system $\mathrm{Cs}_{2} \mathrm{MoO}_{4}-\mathrm{Na}_{2} \mathrm{MoO}_{4}-\mathrm{CoMoO}_{4}$. Proc. Dokl. School-conference of young scientists "Inorganic compounds and functional materials (ICFM-2015)". Novosibirsk: Publishing house of the Institute of inorganic chemistry SB RAS, 2015. P. 139. 
49. D’Yvoire F., Bretey E., Collin G. Crystal structure, non-stoichiometry and conductivity of II- $\mathrm{Na}_{3} \mathrm{M}_{2}\left(\mathrm{AsO}_{4}\right)_{3}(M=\mathrm{Al}, \mathrm{Ga}, \mathrm{Cr}, \mathrm{Fe})$. Solid State Ionics. 1988;28-30:12591264. doi: 10.1016/0167-2738(88)90367-0.

50. Zolotova E. S., Solodovnikova Z. A., Yudin V. N., Solodovnikov S. F., Khaikina E. G., Basovich O. M., Korolkov I. V., Filatova I. Yu. Phase relations in the $\mathrm{Na}_{2} \mathrm{MoO}_{4}-\mathrm{Cs}_{2} \mathrm{MoO}_{4}$ and $\mathrm{Na}_{2} \mathrm{MoO}_{4}-\mathrm{Cs}_{2} \mathrm{MoO}_{4}-\mathrm{ZnMoO}_{4}$ systems, crystal structures of $\mathrm{Cs}_{3} \mathrm{Na}\left(\mathrm{MoO}_{4}\right)_{2}$ and $\mathrm{Cs}_{3} \mathrm{NaZn}_{2}\left(\mathrm{MoO}_{4}\right)_{4}$. J. Solid State Chem. 2015 (accepted for publication).

51. Gudkova I. A. Phase equilibria, synthesis, structure and properties of compounds formed in ternary systems $\mathrm{Li}_{2} \mathrm{MoO}_{4}-A_{2} \mathrm{MoO}_{4}-\mathrm{MMoO}_{4}(A=\mathrm{Na}, \mathrm{K}, \mathrm{Rb}, \mathrm{Cs} ; M=\mathrm{Ca}$, $\mathrm{Sr}, \mathrm{Pb}, \mathrm{Ba}, \mathrm{Cd})$. Dis. Cand. chem. Sci., Novosibirsk, 2014. 192 p. 
Е. Г. Хайкина ${ }^{1,2}$, С. Ф. Солодовников ${ }^{3,4}$, О. М. Басович ${ }^{1}$, 3. А. Солодовникова ${ }^{3}$, Ю. М. Кадырова ${ }^{1}$, А. А. Савина ${ }^{1,2}$, Е. С. Золотова ${ }^{3}$, В. Н. Юдин ${ }^{3,4}$, Т. С. Спиридонова ${ }^{1,2}$

${ }^{1}$ ФГБУН Байкальский институт природопользования СО РАН, 670047, г. Улан-Удэ, ул. Сахьяновой, 6

${ }^{2}$ ФГБОУ ВПО «Бурятский государственный университет»,

670000, г. Улан-Удэ, ул. Смолина, $24 a$

${ }^{3}$ ФГБУН Институт неорганической химии им.

А.В. Николаева СО РАН, 630090, г. Новосибирск, пр. Акад. Лаврентьева, 3

${ }^{4}$ ФГАОУ ВО «Новосибирский национальный исследовательский государственный университет", 630090, г. Новосибирск, ул. Пирогова, 2 egkha@mail.ru,solod@niic.nsc.ru

\section{Тройные молибдаты одно-, одно- и трех(двух)валентных металлов}

В обзоре обобщен экспериментальный материал по фазообразованию, структуре и свойствам новых групп сложнооксидных соединений - тройных молибдатов, содержащих тетраэдрический молибдат-ион, два различных однозарядных катиона наряду с трех- или двухзарядным катионом. Выделено несколько структурных семейств данных соединений и показано, что многие из них представляют интерес как люминесцентные, лазерные, ионопроводящие или нелинейно-оптические материалы.

\footnotetext{
Ключевые слова: тройные молибдаты; одно-, двух- и трехвалентные металлы; фазообразование; структура; функциональные свойства.

Авторы благодарят к.х.н. К. М. Хальбаеву, к.х.н. И. А. Гудкову и к.х.н. И. В. Королькова за участие в исследованиях.

Работа выполнена при частичной поддержке Российского фонда фундаментальных исследований (проекты № 08-03-00384, 13-03-01020 и 14-03-00298).

(C) Хайкина Е. Г., Солодовников С. Ф., Басович О. М., Солодовникова З. А., Кадырова Ю. М., Савина А. А., Золотова Е. С., Юдин В. Н., Спиридонова Т. С., 2015
}

Молибдаты и вольфраматы являются одними из наиболее востребованных объектов неорганической химии, кристаллохимии и химии твер- дого тела, а также базой для разработки функциональных материалов различного назначения, что поддерживает постоянный интерес к данным соедине- 
ниям и объясняет значительное число публикаций по этой тематике.

В 1960-1980 гг. в центре внимания ученых оказались двойные молибдаты и вольфраматы - фазы с общей формулой $A_{x} B_{y}\left(\mathrm{XO}_{4}\right)_{z}$, на основе которых были впоследствии разработаны лазерные, сегнетоэлектрические, сцинтилляционные, нелинейно-оптические и другие материалы [1-5]. Определяющий вклад в формирование этой группы соединений и их всестороннее изучение внесли отечественные научные школы: профессора Л. М. Ковбы, профессора В. К. Трунова (Московский государственный университет им. М. В. Ломоносова), профессора В. М. Жуковского, профессора Е. В. Ткаченко (Уральский государственный университет им. А. М. Горького, г. Свердловск), чл.корр. АН СССР М. В. Мохосоева (Донецкий государственный университет; Бурятский институт естественных наук СО АН СССР, Улан-Удэ), профессора А. А. Майера (Московский химико-технологический институт им. Д. И. Менделеева), профессора А. М. Голуба (Киевский государственный университет), к. ф-м. н. П. В. Клевцова, к.ф.-м.н. Р. Ф. Клевцовой (Ин-

\section{Тройные молибдаты типа 1-1-3}

Первые систематические поисковые исследования тройных молибдатов одно-, одно-, трехвалентных металлов были проведены для литийсодержащих систем $\mathrm{Li}_{2} \mathrm{MoO}_{4}{ }^{-}$ $M_{2} \mathrm{MoO}_{4}-R_{2}\left(\mathrm{MoO}_{4}\right)_{3}(M=\mathrm{K}-\mathrm{Cs}, \mathrm{Tl}, \mathrm{Ag}$, $R=\mathrm{Bi}, L n, \mathrm{Y}, \mathrm{In}, \mathrm{Sc}, \mathrm{Fe}, \mathrm{Ga}, \mathrm{Cr}, \mathrm{Al}) . \mathrm{hx}$ результатом стали выявление, синтез и характеризация около 40 соединений составов LiMR $2\left(\mathrm{MoO}_{4}\right)_{4}, \mathrm{Li} M_{2} R\left(\mathrm{MoO}_{4}\right)_{3}$, $\mathrm{Li}_{2} M_{3} R\left(\mathrm{MoO}_{4}\right)_{4}, \quad \quad \mathrm{Li}_{4} R\left(\mathrm{MoO}_{4}\right)_{4}$, ститут неорганической химии СО АН СССР, г. Новосибирск) и др.

В последние два десятилетия произошло перенесение центра тяжести исследований с двойных молибдатов и вольфраматов на тройные молибдаты. К настоящему времени эта группа соединений насчитывает более 550 представителей и является наиболее быстро растущей среди сложнооксидных фаз, содержащих тетраэдрический анион и три различных катиона. Большая часть тройных молибдатов получена и охарактеризована сотрудниками Байкальского института природопользования СО РАН (г. УланУдэ) и Института неорганической химии им. А. В. Николаева СО РАН (г. Новосибирск). Краткий обзор различных типов тройных молибдатов, отличающихся комбинациями зарядов входящих в них катионов, был ранее представлен в [6]. Целью настоящей работы является более подробное рассмотрение фазообразования, строения и свойств тройных молибдатов, содержащих в своем составе два различных однозарядных катиона наряду с трехзарядным (тип 1-1-3) или двухзарядным (тип 1-1-2) катионом.

$\mathrm{Li}_{2} M R\left(\mathrm{MoO}_{4}\right)_{3}$, что положило начало формированию обширной группы тройных молибдатов типа 1-1-3. Типичные варианты триангуляции систем, в которых эти фазы образуются, представлены на рис. 1. Установлена принадлежность рассматриваемых соединений к восьми структурным типам, для представителей пяти из которых получены кристаллы и определены кристаллические структуры. 
Тройные молибдаты самой многочисленной изоструктурной серии соединений состава $\mathrm{LiMR}_{2}\left(\mathrm{MoO}_{4}\right)_{4}$ образуются с висмутом и некоторыми лантаноидами на квазибинарных разрезах $\mathrm{Li} R\left(\mathrm{MoO}_{4}\right)_{2}-M R\left(\mathrm{MoO}_{4}\right)_{2}$ систем $\mathrm{Li}_{2} \mathrm{MoO}_{4}-M_{2} \mathrm{MoO}_{4}-R_{2}\left(\mathrm{MoO}_{4}\right)_{3}(M=\mathrm{K}$, $\mathrm{Rb}, \mathrm{Tl})$. Области существования этих фаз в ряду РЗЭ существенно различаются и с ростом размера однозарядного катиона сдвигаются в сторону легких лантаноидов (рис. 2).

Анализ экспериментальных данных позволяет сделать вывод об определяющем влиянии размерного фактора на возможность формирования моноклинных тройных молибдатов данного семейства: $\mathrm{LiMLn}{ }_{2}\left(\mathrm{MoO}_{4}\right)_{4}$ образуются, если разница в размерах ионов крупного однозарядного катиона и редкоземельного элемента заключена в интервале

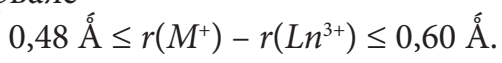

При более низких значениях $\Delta r$ на разрезе $\mathrm{Li} \operatorname{Ln}\left(\mathrm{MoO}_{4}\right)_{2}-M \operatorname{Ln}\left(\mathrm{MoO}_{4}\right)_{2}$ происходит формирование твердых рас-

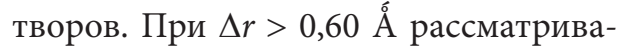
емая фаза либо не образуется, либо ее формирование настолько затруднено, что соединение не удается выделить в однофазном состоянии при использовании обычных методик твердофазного синтеза [11].

В установленный интервал укладываются и изоформульные и изоструктурные медьсодержащие соединения
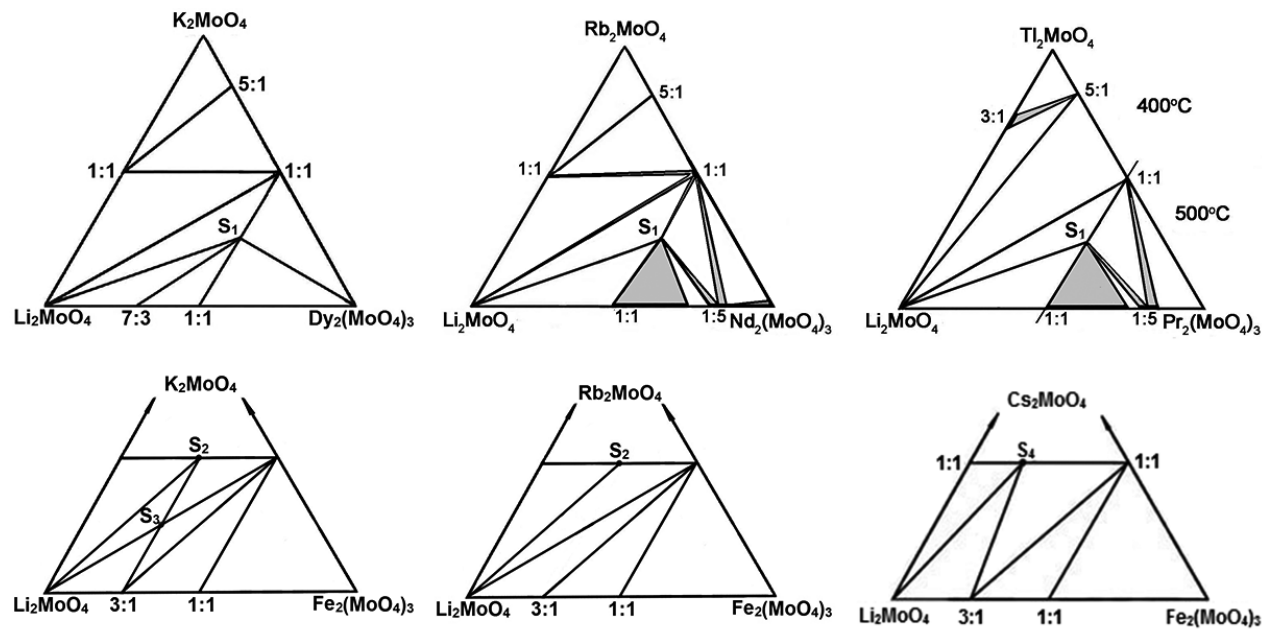

Рис. 1. Субсолидусное строение некоторых систем $\mathrm{Li}_{2} \mathrm{MoO}_{4}-M_{2} \mathrm{MoO}_{4}-R_{2}\left(\mathrm{MoO}_{4}\right)_{3}$ [7-10]:

$S_{1}-\mathrm{LiMR}_{2}\left(\mathrm{MoO}_{4}\right)_{4} ; S_{2}-\mathrm{Li}_{2} R\left(\mathrm{MoO}_{4}\right)_{3} ; S_{3}-\mathrm{Li}_{2} M R\left(\mathrm{MoO}_{4}\right)_{3} ; S_{4}-\mathrm{Li}_{2} M_{3} R\left(\mathrm{MoO}_{4}\right)_{4}$. Область $\mathrm{LiMMoO}_{4}-\mathrm{M}_{2} \mathrm{MoO}_{4}-\mathrm{MFe}\left(\mathrm{MoO}_{4}\right)_{2}$ систем $\mathrm{Li}_{2} \mathrm{MoO}_{4}-M_{2} \mathrm{MoO}_{4}-\mathrm{Fe}_{2}\left(\mathrm{MoO}_{4}\right)_{3}$ $(M=\mathrm{K}, \mathrm{Rb}, \mathrm{Cs})$

\begin{tabular}{c|c|c|c|c|c}
\hline $\boldsymbol{M}$ & La & Ce, Pr & Nd & Sm, Eu & Gd-Lu, Y \\
\hline $\mathrm{K}$ & & & & & \\
\hline $\mathrm{Tl}$ & & & & & \\
\hline $\mathrm{Rb}$ & & & & &
\end{tabular}

Рис. 2. Области существования тройных молибдатов $\operatorname{LiMLn_{2}}\left(\mathrm{MoO}_{4}\right)_{4}$ (заштрихованы) 
№ 4 | 2015

Chimica Techno Acta

$\mathrm{CuKLn} n_{2}\left(\mathrm{MoO}_{4}\right)_{4}$ с Gd, Tb, Но, полученные и охарактеризованные в $[12,13]$. Близость $r\left(\mathrm{Cu}^{+}\right)$и $r\left(\mathrm{Li}^{+}\right)$позволяет с высокой степенью вероятности прогнозировать существенное расширение семейства тройных молибдатов $M^{\prime} M^{\prime \prime} R_{2}\left(\mathrm{MoO}_{4}\right)_{4}$ за счет содержащих $\mathrm{Cu}(\mathrm{I})$ фаз подобного типа с $\mathrm{K}, \mathrm{Tl}, \mathrm{Rb}$ и теми трехвалентными элементами, разница в размерах с которыми будет удовлетворять предложенному критерию.

Строение тройных молибдатов $\mathrm{LiMR} 2\left(\mathrm{MoO}_{4}\right)_{4}$ определено на примере $\mathrm{LiRbBi}_{2}\left(\mathrm{MoO}_{4}\right)_{4}$, единственного соединения данного семейства, плавящегося конгруэнтно [14]. Остальные соединения $\mathrm{LiMR}\left(\mathrm{MoO}_{4}\right)_{4}$ разлагаются в твердой фазе на соответствующие двойные молибдаты $[7,15]^{1}$ и их структуры (на примере $\mathrm{LiMNd}\left(\mathrm{MoO}_{4}\right)_{4}$, $M=\mathrm{K}, \mathrm{Tl}, \mathrm{Rb}$ уточняли методом Ритвельда по порошковым данным [16]. Структуры $\mathrm{LiMR}\left(\mathrm{MoO}_{4}\right)_{4} \quad$ близки к строению тройных молибдатов $\mathrm{Li}_{3} \mathrm{Ba}_{2} \operatorname{Ln}_{3}\left(\mathrm{MoO}_{4}\right)_{8}$ [17] и производны от структурного типа $\mathrm{BaNd}_{2}\left(\mathrm{MoO}_{4}\right)_{4}[18]$. Характерной особенностью структур $\mathrm{LiMR}\left(\mathrm{MoO}_{4}\right)_{4}$ являются ажурные слои из полиэдров $R_{8}$ и присоединенных к ним через общие вершины $\mathrm{MoO}_{4}$ тетраэдров. Соседние слои связаны между собой посредством октаэдров $\mathrm{LiO}_{6}$ и полиэдров $\mathrm{MO}_{10}$ (рис. 3).

Наличие в соединениях $\mathrm{LiMR} 2\left(\mathrm{MoO}_{4}\right)_{4}$ ионов $\mathrm{Li}^{+}$, заполняющих междоузельные пустоты структурного типа $\mathrm{BaNd}_{2}\left(\mathrm{MoO}_{4}\right)$, позволяет предполагать у них литий-ионную

1 Распад LiMCe $2\left(\mathrm{MoO}_{4}\right)_{4}$ при нагревании на воздухе сопровождается частичным окислением $\mathrm{Ce}^{3+}$ до $\mathrm{Ce}^{4+}$. проводимость. Результаты указывают на возможность использования этих тройных молибдатов как чувствительных элементов датчиков сенсорных систем оперативного мониторинга окружающейсреды $[19,20]$. Спектрально-люминесцентные характеристики $\mathrm{LiMLn} n_{2}\left(\mathrm{MoO}_{4}\right)_{4}: \mathrm{Eu}^{3+}\left(\mathrm{Nd}^{3+}\right)$ дают основание говорить о возможности применения тройных молибдатов этого семейства для создания люминофоров, обладающих высокой контрастностью цветов, а также активных сред лазеров $[8,21]$. О перспективности использования $\mathrm{LiKGd}_{2}\left(\mathrm{MoO}_{4}\right)_{4}: \mathrm{Eu}^{3+}$ в качестве красного люминофора для WLED-свидетельствуют данные, полученные в [22].

Как и в предыдущем случае, возможность образования другой изоструктурной серии тройных молибдатов $\mathrm{Li}_{2} M_{3} R\left(\mathrm{MoO}_{4}\right)_{4}(M R=\mathrm{CsFe}, \mathrm{CsGa}$, $\mathrm{RbGa}, \mathrm{CsAl}, \mathrm{RbAl}, \mathrm{TlAl})$ в значительной мере определяется размерным фактором: соединения образованы малыми катионами $\mathrm{Fe}^{3+}, \mathrm{Ga}^{3+}, \mathrm{Al}^{3+}$ с тетраэдрической координацией и достаточно крупными ионами $\mathrm{Tl}^{+}, \mathrm{Rb}^{+}$и $\mathrm{Cs}^{+}$. Отсутствие $\mathrm{Li}_{2} \mathrm{M}_{3} \mathrm{Cr}\left(\mathrm{MoO}_{4}\right)_{4}$ связано, видимо, с высокой предпочтительностью $\mathrm{Cr}^{3+}$ к октаэдрической координации.

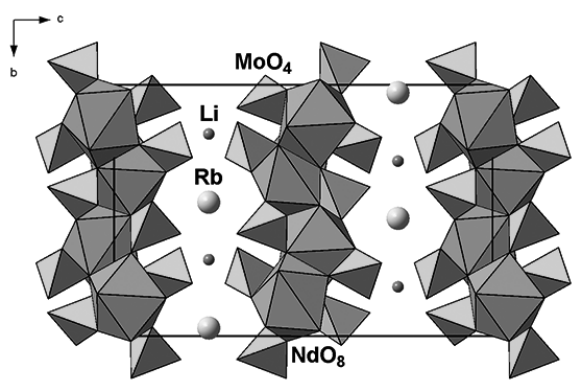

Рис. 3. Проекция структуры $\mathrm{LiRbNd}_{2}\left(\mathrm{MoO}_{4}\right)_{4}$ вдоль оси $a$ 
Эти тетрагональные соединения обладают каркасным строением и являются упорядоченными производными кубического $\mathrm{Cs}_{6} \mathrm{Zn}_{5}\left(\mathrm{MoO}_{4}\right)_{8}[23,24]$. C увеличением размера $R^{3+}$ область существования подобных фаз смещается в сторону более крупных однозарядных катионов $M^{+}$, что можно объяснить соответствием размеров тетраэдрического каркаса размерам внекаркасного катиона. Очевидно, именно с размерным несоответствием связана кристаллизация $\mathrm{Li}_{2} \mathrm{~K}_{3} \mathrm{Al}\left(\mathrm{MoO}_{4}\right)_{4}$ в другом структурном типе [10].

Показано, что $\mathrm{LiK}_{2} \mathrm{In}\left(\mathrm{MoO}_{4}\right)_{3}$, $\mathrm{LiRb}_{2} \mathrm{Fe}\left(\mathrm{MoO}_{4}\right)_{3}$ и $\mathrm{LiCs}_{4} \mathrm{Al}\left(\mathrm{MoO}_{4}\right)_{4}$ формируют новые структурные типы, не имеющие пока других представителей (табл. 1). Получить пригодные для рентгеноструктурных исследова- ний монокристаллы $\mathrm{LiK}_{2} \mathrm{Fe}\left(\mathrm{MoO}_{4}\right)_{3}$, $\mathrm{Li}_{2} \mathrm{KFe}\left(\mathrm{MoO}_{4}\right)_{3}$ и $\mathrm{Li}_{2} \mathrm{~K}_{3} \mathrm{Al}\left(\mathrm{MoO}_{4}\right)_{4}$, либо найти структурные прототипы этих соединений пока не удалось.

Ни в одной из систем $\mathrm{Li}_{2} \mathrm{MoO}_{4}-$ $\mathrm{Ag}_{2} \mathrm{MoO}_{4}-R_{2}\left(\mathrm{MoO}_{4}\right)_{3}$ тройные молибдаты не выявлены [28-30]. Разрезы $\mathrm{Li} R\left(\mathrm{MoO}_{4}\right)_{2}-\mathrm{Ag} R\left(\mathrm{MoO}_{4}\right)_{2}$ в висмут- и лантаноидсодержащих системах характеризуются формированием про-

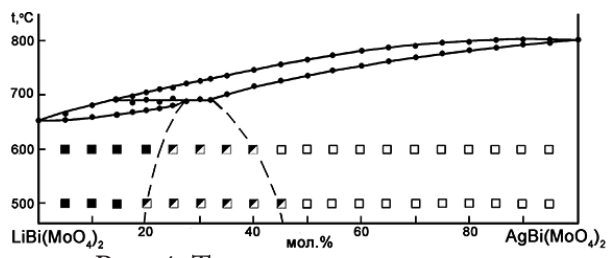

Рис. 4. Т-х-диаграмма разреза

$\mathrm{LiBi}\left(\mathrm{MoO}_{4}\right)_{2}-\mathrm{AgBi}\left(\mathrm{MoO}_{4}\right)_{2}[29]$

Таблица 1

Данные РСА монокристаллов $\mathrm{LiK}_{2} \operatorname{In}\left(\mathrm{MoO}_{4}\right)_{3}$, $\mathrm{LiRb} 2 \mathrm{Fe}(\mathrm{MoO} 4) 3$ и $\mathrm{LiCs} 4 \mathrm{Al}(\mathrm{MoO} 4) 4$ [25-27]

\begin{tabular}{c|c|c|c|c|c|c} 
Соединение & Пр. гр.; $\mathrm{Z}$ & $a, \AA$ & $b, \AA$ & $c, \AA$ & $\beta,{ }^{\circ}$ & $R, \%$ \\
\hline $\mathrm{LiK}_{2} \operatorname{In}\left(\mathrm{MoO}_{4}\right)_{3}$ & $P 2_{1} ; 2$ & $7.0087(2)$ & $9.2269(3)$ & $10.1289(3)$ & $107.401(1)$ & 22.80 \\
\hline $\mathrm{LiRb}_{2} \mathrm{Fe}\left(\mathrm{MoO}_{4}\right)_{3}$ & $P n m a ; 4$ & $24.3956(6)$ & $5.8306(1)$ & $8.4368(2)$ & - & 2.11 \\
\hline $\mathrm{LiCs}_{4} \mathrm{Al}\left(\mathrm{MoO}_{4}\right)_{4}$ & $P 2 ; 2$ & $15.940(3)$ & $8.266(2)$ & $8.319(2)$ & $105.13(3)$ & 2.85
\end{tabular}

Таблица 2

Тройные молибдаты в системах $M_{2} \mathrm{MoO}_{4}-\mathrm{Cs}_{2} \mathrm{MoO}_{4}-R_{2}\left(\mathrm{MoO}_{4}\right)_{3}(M=\mathrm{Na}, R=\mathrm{Bi}, \mathrm{Ln}, \mathrm{In}, \mathrm{Sc}$, Fe; $M=\mathrm{Ag}, R=\mathrm{Bi}, \mathrm{Ln}, \mathrm{In}, \mathrm{Sc})[31,32]$

\begin{tabular}{|c|c|c|c|c|c|c|c|c|c|c|c|c|c|}
\hline & \multicolumn{7}{|c|}{$M=\mathrm{Na}$} & \multirow{2}{*}{ Phase } & \multicolumn{5}{|c|}{$M=\mathbf{A g}$} \\
\hline & $\mathrm{Bi}$ & Tm & $\mathbf{Y b}$ & Lu & In & Sc & $\mathrm{Fe}$ & & $\mathbf{B i}$ & $\mathbf{Y b}$ & Lu & In & Sc \\
\hline$S_{1}$ & * & * & & & & & & $M_{13-3 x} \mathrm{Cs}_{11} R_{2+x}\left(\mathrm{MoO}_{4}\right)_{15}$ & & & & & \\
\hline $\mathrm{S}_{2}$ & & & * & & & & & $M_{5} \mathrm{Cs}_{7} R_{2}\left(\mathrm{MoO}_{4}\right)_{9}$ & & & & & \\
\hline$S_{3}$ & * & & & & & & & $M \mathrm{Ms}_{2} R\left(\mathrm{MoO}_{4}\right)_{3}$ & $\cdot$ & & & & \\
\hline$S_{4}$ & & & & & $\frac{{ }^{*} \mathrm{~B} / \mathrm{T}}{\mathbf{H} / \mathbf{T}}$ & & & $M_{3} \mathrm{Cs}_{3} R_{2}\left(\mathrm{MoO}_{4}\right)_{6}$ & & & & & \\
\hline$S_{5}$ & & & & & * & * & * & $M_{25} \mathrm{Cs}_{8} R_{5}\left(\mathrm{MoO}_{4}\right)_{24}$ & & & & & \\
\hline
\end{tabular}

поля соединений, построенных на единой структурной основе, заштрихованы одинаково;

* - получены кристаллы и по монокристальным данным методом РСА определена структура;

- - получены кристаллы и по монокристальным данным определены параметры ячейки 
№ 4 | 2015

Chimica Techno Acta тяженных граничных твердых растворов (рис. 4).

Выполненные в последние годы исследования систем $M_{2} \mathrm{M} \mathrm{oOO}_{4}-\mathrm{Cs}_{2} \mathrm{MoO}_{4}-R_{2}\left(\mathrm{MoO}_{4}\right)_{3}$ $(M=\mathrm{Na}, \mathrm{Ag})$ позволили значительно пополнить группу тройных молибдатов одно- и трехвалентных металлов за счет натрий- и серебросодержащих фаз. Составы и области существования полученных при этом соединений приведены в табл. 2, данные РСА полученных монокристаллов - в табл. 3 .

Изученные натриевые соединения имеют, как правило, сложные составы и каркасные структуры (рис. 5, 6), отличные по своему строению от тройных молибдатов, образующихся в системах $\mathrm{Li}_{2} \mathrm{MoO}_{4}-M_{2} \mathrm{MoO}_{4}-R_{2}\left(\mathrm{MoO}_{4}\right)_{3}$ $(M=\mathrm{K}-\mathrm{Cs}, \mathrm{Tl})$. В структурах натрийсодержащих тройных молибдатов присутствуют $\mathrm{MoO}_{4}$-тетраэдры и $R \mathrm{O}_{6}$-октаэдры, а натрий обладает октаэдрической или тригонально-призматической координацией, либо формирует полиэдры с более низким КЧ. В этих структурах $\mathrm{Na}^{+}$и $R^{3+}$ достаточно часто совместно заселяют одни кристаллографические позиции; наряду с ними имеются позиции, частично заполненные катионами натрия, что приводит к отклонению составов от стехиометрических. Фазы переменного состава широко распространены среди сложных (двойных и тройных) натриевых молибдатов [33, 34], что обусловлено близостью размеров ионов $\mathrm{Na}^{+}$и $A^{2+}$ или $R^{3+}$.

Согласно данным РФА, все тройные молибдаты, обнаруженные в системах $\mathrm{Ag}_{2} \mathrm{MoO}_{4}-\mathrm{Cs}_{2} \mathrm{MoO}_{4}-R_{2}\left(\mathrm{MoO}_{4}\right)_{3}$, изоформульны натриевым аналогам и построены на единой с ними структурной основе [32].

В практическом плане наиболее интересны тройные молибдаты $\mathrm{Na}_{25} \mathrm{Cs}_{8} R_{5}\left(\mathrm{MoO}_{4}\right)_{24}$, близко родственные структуры которых решены по монокристальным данным в рамках пр. гр. $P 2_{1} / c$ (In), $P 2_{1} 2_{1} 2_{1}(\mathrm{Sc}), P \overline{1}$ (Fe) $[38,39]$. Атомы Мо во всех трех структурах координированы тетраэдрически, трехвалентного металла - октаэдрически, причем все или часть из

Таблица 3

Данные РСА монокристаллов тройных молибдатов натрия, цезия и трехвалентных металлов [31]

\begin{tabular}{c|c|c|c|c} 
& Соединение & Пр. гр.; $Z$ & Параметры решетки & $R$ \\
\hline \multirow{2}{*}{$S_{1}$} & $\mathrm{Na}_{723} \mathrm{Cs}_{11} \mathrm{Tm}_{392}\left(\mathrm{MoO}_{4}\right)_{15}$ & $P 6_{3} / m c m ; 2$ & $a=10.5849(1), c=37.4867(6) \AA$ & 0,029 \\
\cline { 2 - 6 } & $\mathrm{Na}_{772} \mathrm{Cs}_{11} \mathrm{Bi}_{376}\left(\mathrm{MoO}_{4}\right)_{15}$ & $P 6_{3} / m c m ; 2$ & $a=10.5507(1), c=37.6640(1) \AA$ & 0,038 \\
\hline$S_{2}$ & $\mathrm{Na}_{5} \mathrm{Cs}_{7} \mathrm{Yb}_{2}\left(\mathrm{MoO}_{4}\right)_{9}$ & $R 32 ; 3$ & $a=10.5107(2), c=36.358(7) \AA$ & 0,035 \\
\hline$S_{3}$ & $\mathrm{NaCs}_{2} \mathrm{Bi}_{2}\left(\mathrm{MoO}_{4}\right)_{3}$ & $R 3 c ; 12$ & $a=10.6435(2), c=40.9524(7) \AA$ & 0,020 \\
\hline \multirow{2}{*}{$S_{4}$} & $\mathrm{в}_{\mathrm{T}}-\mathrm{Na}_{3} \mathrm{Cs}_{3} \mathrm{In}_{2}\left(\mathrm{MoO}_{4}\right)_{6}$ & $R \overline{\mathbf{3}} ; 12$ & $a=17.5753(2), c=29.4333(3) \AA$ & 0,032 \\
\hline \multirow{2}{*}{$S_{5}$} & $\mathrm{Na}_{25} \mathrm{Cs}_{8} \mathrm{In}_{5}\left(\mathrm{MoO}_{4}\right)_{24}$ & $P 2_{1} / c ; 4$ & $\begin{array}{c}a=12.6392(2), b=21.4601(4), \\
c=14.0313(3) \AA, \beta=90.017(1)^{\circ}\end{array}$ & 0,030 \\
\cline { 2 - 6 } & $\mathrm{Na}_{25} \mathrm{Cs}_{8} \mathrm{Sc}_{5}\left(\mathrm{MoO}_{4}\right)_{24}$ & $P 2_{1} 2_{1} 2_{1} ; 2$ & $\begin{array}{c}a=28.6452(6), b=14.0043(3), \\
c=12.6482(2) \AA\end{array}$ & 0,072 \\
\cline { 2 - 6 } & $\mathrm{Na}_{25} \mathrm{Cs}_{8} \mathrm{Fe}_{5}\left(\mathrm{MoO}_{4}\right)_{24}$ & $P \overline{1} ; 2$ & $\begin{array}{c}a=12.5814(5), b=13.8989(5), \\
c=28.4386(9) \AA, \alpha=90.108(2), \\
\beta\end{array}$ & 0,044
\end{tabular}


них заселяют свои позиции совместно с атомами натрия. Оставшиеся атомы $\mathrm{Na}$ имеют довольно искаженную кислородную координацию (КЧ $=5$ и 6); у атомов цезия КЧ $=9-10$ (In),
11 (Sc), 10-12 (Fe); некоторые позиции катионов натрия могут быть заселены частично. Во всех структурах можно выделить полиэдрические слои, образованные парами сочле-

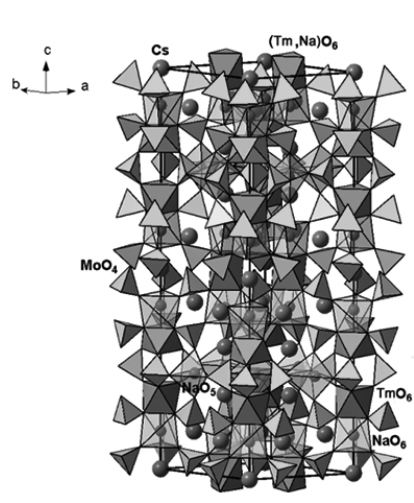

$a$

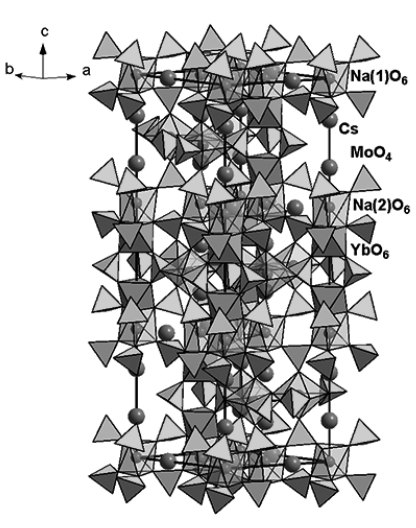

6

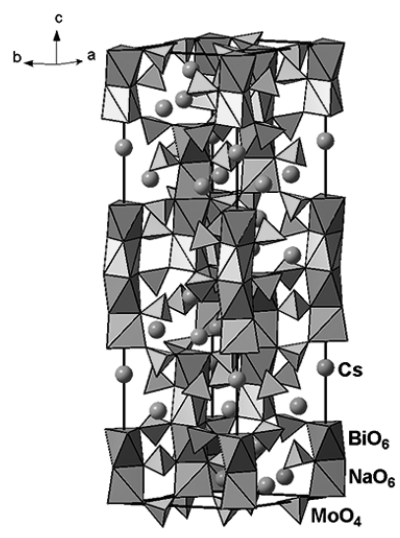

8

Рис. 5. Структуры $\mathrm{Na}_{7.23} \mathrm{Cs}_{11} \operatorname{Tm}_{3.92}\left(\mathrm{MoO}_{4}\right)_{15}(a), \mathrm{Na}_{5} \mathrm{Cs}_{7} \mathrm{Yb}_{2}\left(\mathrm{MoO}_{4}\right)_{9}($ (6), $\mathrm{NaCs}_{2} \mathrm{Bi}\left(\mathrm{MoO}_{4}\right)_{3}(6)$ [35-37]
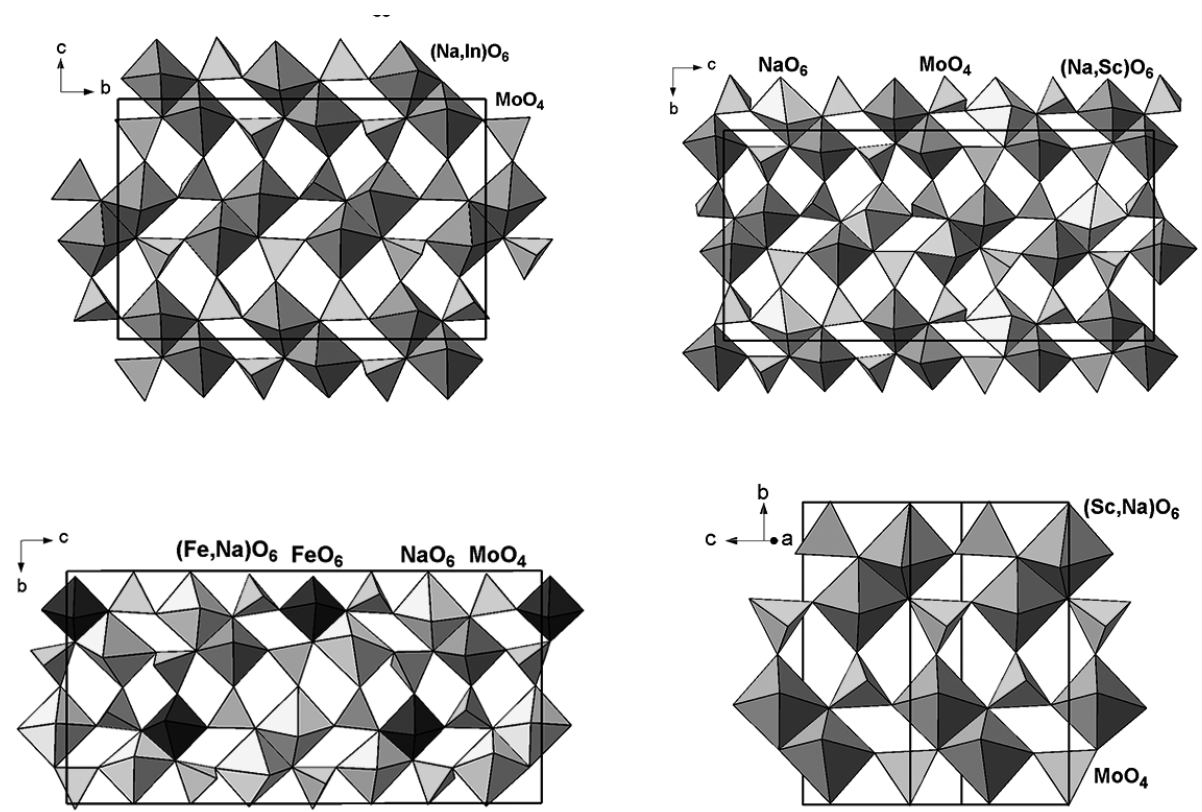

Рис. 6. Полиэдрические фрагменты (слои) в структурах $\mathrm{Na}_{25} \mathrm{Cs}_{8} \operatorname{In}_{5}\left(\mathrm{MoO}_{4}\right)_{24}(a)$, $\mathrm{Na}_{25} \mathrm{Cs}_{8} \mathrm{Sc}_{5}\left(\mathrm{MoO}_{4}\right)_{24}\left(\right.$ б), $\mathrm{Na}_{25} \mathrm{Cs}_{8} \mathrm{Fe}_{5}\left(\mathrm{MoO}_{4}\right)_{24}($ ( ) $), \mathrm{Na}_{5} \mathrm{Sc}\left(\mathrm{MoO}_{4}\right)_{4}(2)$ [38] 
ненных по ребрам октаэдров $(R, \mathrm{Na})$ $\mathrm{O}_{6}$ и $(R, \mathrm{Na}) \mathrm{O}_{6}$ (или $\left.\mathrm{RO}_{6}\right)$, которые соединены вершинами c мостиковыми $\mathrm{MoO}_{4}$-тетраэдрами (рис. 6, a-8). Слои связываются мостиковыми $\mathrm{MoO}_{4}$-тетраэдрами в трехмерный каркас, в пустотах которого расположены катионы $\mathrm{Cs}^{+}$и $\mathrm{Na}^{+}$. Во всех случаях строение слоев восходит к полиэдрическому слою из структуры $\mathrm{Na}_{5} \mathrm{Sc}\left(\mathrm{MoO}_{4}\right)_{4}$ (рис. 6, 2), относящейся к типу аллюодита $(\mathrm{Na}, \mathrm{Ca})(\mathrm{Fe}, \mathrm{Mn}, \mathrm{Mg})_{3}\left(\mathrm{PO}_{4}\right)_{3}$ [40]. Ромбическая или псевдоромбическая метрика ячеек тройных молибдатов возникает из-за некоторого взаимного сдвига слоев по сравнению с моноклинными $\mathrm{Na}_{5} \mathrm{Sc}\left(\mathrm{MoO}_{4}\right)_{4}$ и аллюодитом (пр. гр. C2/c), что может быть связано с наличием катионов цезия между слоями. Особенности строения данной группы тройных молибдатов позволяют считать ее не разновидностью структурного типа аллюодита, а отдельным, хотя и близко родственным, структурным семейством.

\section{Тройные молибдаты типа 1-1-2}

Среди тройных солевых систем $M_{2} \mathrm{MoO}_{4}-M^{\prime \prime}{ }_{2} \mathrm{MoO}_{4}-A_{\mathrm{MoO}}$ к настоящему времени наиболее изучены системы, образованные молибдатами лития, тяжелых щелочных элементов (K, Rb, Cs) и $\mathrm{Mg}, \mathrm{Mn}, \mathrm{Co}, \mathrm{Ni}, \mathrm{Co}, \mathrm{Zn}, \mathrm{Cd}$, $\mathrm{Ca}, \mathrm{Sr}, \mathrm{Ba}, \mathrm{Pb}$. Большинство этих систем не являются фазообразующими, в некоторых формируются твердые растворы на основе двойных молибдатов. В шести системах найдено по одному тройному молибдату; их характеристики представлены в табл. 4 .

В тройных системах $\mathrm{Li}_{2} \mathrm{MoO}_{4}-$ $\mathrm{K}_{2} \mathrm{MoO}_{4}-\mathrm{AMoO}_{4}(A=\mathrm{Mg}, \mathrm{Mn}$,
Исследование ионопроводящих свойств аллюодитоподобных тройных молибдатов показало, что данные соединения претерпевают обратимые фазовые переходы I рода, сопровождаемые скачкообразным увеличением проводимости. Выше температур фазовых переходов электропроводность достигает значений $10^{-2}-10^{-3} \mathrm{CM} / \mathrm{cm}$, что дает возможность рассматривать $\mathrm{Na}_{25} \mathrm{Cs}_{8} R_{5}\left(\mathrm{MoO}_{4}\right)_{24}(R=\mathrm{In}, \mathrm{Sc}, \mathrm{Fe})$ как перспективные объекты для разработки новых материалов с высокой ионной проводимостью $[38,39]$.

Особенности строения ряда других описанных выше тройных молибдатов также позволяют ожидать проявления ими повышенной натрий(серебро)ионной проводимости, причем улучшения их проводящих характеристик, по-видимому, можно добиться подходящими гетеровалентными замещениями с заменой части натрия (серебра) или другого катиона в структуре на более высокозарядный и образованием вакансий.

Со) на квазибинарных разрезах $\mathrm{Li}_{2} A_{2}\left(\mathrm{MoO}_{4}\right)_{3}-\mathrm{K}_{2} A_{2}\left(\mathrm{MoO}_{4}\right)_{3}$ (рис. 7) выявлены ромбоэдрические тройные молибдаты $\mathrm{K}_{3+x} \mathrm{Li}_{1-x} A_{4}\left(\mathrm{MoO}_{4}\right)_{6}(0 \leq x \leq 0,3)$ $[42,43]$. Они кристаллизуются в структурном типе II-Na $\mathrm{Fe}_{2}\left(\mathrm{AsO}_{4}\right)_{3}$ [49], в котором катионы распределяются следующим образом: $\left(\mathrm{Na}_{5} \square\right)^{\mathrm{IX}}(M 1)^{\mathrm{VI}}(M 2)$ ${ }^{\mathrm{VI}}(\mathrm{M} 3)_{3}{ }^{\mathrm{VI}}\left(\mathrm{AsO}_{4}\right)_{6}=\left(\mathrm{Na}_{5} \square\right)(\mathrm{Na})\left(\mathrm{Fe}^{3+}\right)$ $\left(\mathrm{Fe}^{3+}\right)_{3}\left(\mathrm{AsO}_{4}\right)_{6}$ (здесь римские цифры обозначают КЧ катионов в позициях $M 1, M 2$ и $M 3$ ). В структурах тройных молибдатов катионы $\mathrm{Li}, A^{2+}$ и часть $\mathrm{K}^{+}$ размещены в позициях $M 1, M 2$ и $M 3$ (рис. 8), а основная часть калия на- 
ходится в позиции с КЧ = 9, занятой наполовину из-за коротких контактов K-К. Присутствие калия в одной позиции с катионами $\mathrm{Mg}^{2+}, \mathrm{Mn}^{2+}, \mathrm{Co}^{2+}$, $\mathrm{Li}^{+}$является редким для кристаллохимии случаем. Найденные по струк- турным данным составы кристаллов подтверждены хорошей сходимостью локальных балансов валентных усилий. Основой всех структур являются трехмерные каркасы из октаэдров вокруг $M 1, M 2$ и $M 3$ и тетраэдров

Таблица 4

Кристаллографические и термические характеристики тройных молибдатов типа 1-1-2 [41-48]

\begin{tabular}{|c|c|c|c|c|c|c|}
\hline \multirow{2}{*}{ Соединение } & \multirow{2}{*}{ Пр. гр.; Z } & \multicolumn{4}{|c|}{ Параметры элементарной ячейки } & \multirow{2}{*}{$\begin{array}{c}\mathrm{T}_{\mathrm{n},} \\
{ }^{\circ} \mathrm{C}\end{array}$} \\
\hline & & & $b, \AA$ & $c, \AA$ & $\beta,^{\circ}$ & \\
\hline $\mathrm{K}_{3,11} \mathrm{Li}_{0,89} \mathrm{Mg}_{4}\left(\mathrm{MoO}_{4}\right)_{6}$ & $R \overline{3} c ; 6$ & $14,3541(2)$ & - & $19,7338(4)$ & - & $730^{*}$ \\
\hline $\mathrm{K}_{3,07} \mathrm{Li}_{0,93} \mathrm{Mn}_{4}\left(\mathrm{MoO}_{4}\right)_{6}$ & $R \overline{3} c ; 6$ & $14,5896(3)$ & - & $19,9773(8)$ & - & 720 \\
\hline $\mathrm{K}_{3,14} \mathrm{Li}_{0,86} \mathrm{Mn}_{4}\left(\mathrm{MoO}_{4}\right)_{6}$ & $R \overline{3} c ; 6$ & $14,607(2)$ & - & $19,992(4)$ & - & - \\
\hline $\mathrm{K}_{3,30} \mathrm{Li}_{0,70} \mathrm{Co}_{4}\left(\mathrm{MoO}_{4}\right)_{6}$ & $R \overline{3} c ; 6$ & $14,4391(3)$ & - & $19,891(1)$ & - & $710^{*}$ \\
\hline $\mathrm{K}_{3} \mathrm{NaNi}_{4}\left(\mathrm{MoO}_{4}\right)_{6}$ & $R \overline{3} c ; 6$ & $14,2790(2)$ & - & $19,7589(4)$ & - & 750 \\
\hline $\mathrm{K}_{3} \mathrm{NaMg}_{4}\left(\mathrm{MoO}_{4}\right)_{6}$ & $R \overline{3} c ; 6$ & $14,4528(2)$ & - & $19,8894(3)$ & - & 720 \\
\hline $\mathrm{K}_{3} \mathrm{NaCo}_{4}\left(\mathrm{MoO}_{4}\right)_{6}$ & $R \overline{3} c ; 6$ & $14,4638(1)$ & - & $19,8369(3)$ & - & $530^{*}$ \\
\hline $\mathrm{Rb}_{3} \mathrm{LiZn}_{2}\left(\mathrm{MoO}_{4}\right)_{4}$ & $I \overline{4} 3 d ; 4$ & $11,902(1)$ & - & - & - & 580 \\
\hline $\mathrm{Cs}_{3} \mathrm{LiCo}_{2}\left(\mathrm{MoO}_{4}\right)_{4}$ & $I \overline{4} 3 d ; 4$ & $12,2239(2)$ & - & - & - & $740^{* *}$ \\
\hline $\mathrm{Cs}_{3} \mathrm{LiZn}_{2}\left(\mathrm{MoO}_{4}\right)_{4}$ & $I \overline{4} 3 d ; 4$ & $12,2100(1)$ & - & - & - & 690 \\
\hline $\mathrm{Cs}_{3} \mathrm{NaZn}_{2}\left(\mathrm{MoO}_{4}\right)_{4}$ & $I \overline{4} 3 d ; 4$ & $12,3134(1)$ & - & - & - & 510 \\
\hline $\mathrm{Cs}_{3} \mathrm{AgZn}_{2}\left(\mathrm{MoO}_{4}\right)_{4}$ & $I \overline{4} 3 d ; 4$ & $12,3049(2)$ & - & - & - & 530 \\
\hline $\mathrm{CsNa}_{5} \mathrm{Mn}_{3}\left(\mathrm{MoO}_{4}\right)_{6}$ & $C 2 / c ; 2$ & $13,3659(3)$ & $13,6897(3)$ & $7,1692(2)$ & $112,727(1)$ & 701 \\
\hline $\mathrm{Cs}_{4} \mathrm{Na}_{10} \mathrm{Mn}_{5}\left(\mathrm{MoO}_{4}\right)_{12}$ & $P 2_{1} / c ; 4$ & $13,8597(3)$ & $12,5719(2)$ & $28,4209(3)$ & $90,097(1)$ & 576 \\
\hline $\mathrm{CsNa}_{5} \mathrm{Co}_{3}\left(\mathrm{MoO}_{4}\right)_{6}$ & $C 2 / c ; 2$ & $13,0917(8)$ & $13,5443(8)$ & $7,1217(4)$ & $112,331(2)$ & 615 \\
\hline $\mathrm{Cs}_{4} \mathrm{Na}_{10} \mathrm{Co}_{5}\left(\mathrm{MoO}_{4}\right)_{12}$ & $P b c a ; 4$ & $13,6572(3)$ & $12,5063(3)$ & $27,9898(5)$ & - & - \\
\hline $\mathrm{CsNa}_{5} \mathrm{Ni}_{3}\left(\mathrm{MoO}_{4}\right)_{6}$ & $C 2 / c ; 2$ & $13,212(3)$ & $12,458(3)$ & $7,120(1)$ & $112,245(3)$ & 636 \\
\hline
\end{tabular}

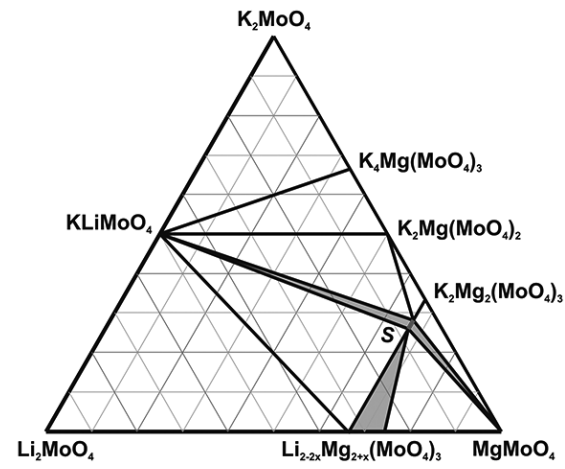

Рис. 7. Субсолидусная триангуляция системы $\mathrm{Li}_{2} \mathrm{MoO}_{4}-\mathrm{K}_{2} \mathrm{MoO}_{4}-\mathrm{MgMoO}_{4}$ при $550^{\circ} \mathrm{C} . S-\mathrm{K}_{3+x} \mathrm{Li}_{1-x} \mathrm{Mg}_{4}\left(\mathrm{MoO}_{4}\right)_{6}$

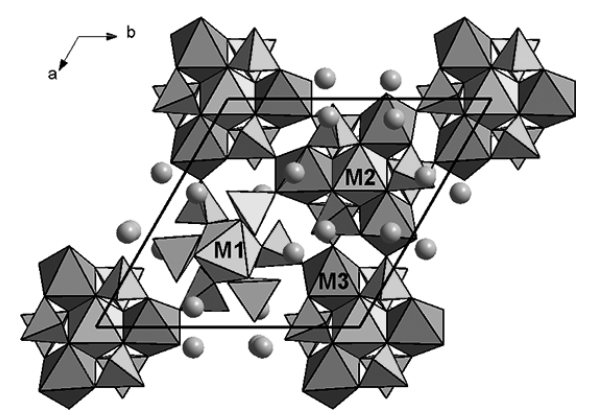

Рис. 8. Проекция фрагмента структуры тройных молибдатов $\mathrm{K}_{3+x} \mathrm{Li}_{1-x} A_{4}\left(\mathrm{MoO}_{4}\right)_{6}$ ( $A=\mathrm{Mg}, \mathrm{Mn}, \mathrm{Co})$ на плоскость (001) 
№ 4 | 2015

Chimica Techno Acta

$\mathrm{MoO}_{4}$, в больших внекаркасных пустотах размещаются ионы калия. В системах $\mathrm{Na}_{2} \mathrm{MoO}_{4}-\mathrm{K}_{2} \mathrm{MoO}_{4}-\mathrm{AMoO}_{4}$ $(A=\mathrm{Ni}, \mathrm{Mg}, \mathrm{Co})$ образуются аналогичные по строению тройные молибдаты $\mathrm{K}_{3} \mathrm{Na}_{4}\left(\mathrm{MoO}_{4}\right)_{6}$ [44], фигуративные точки которых расположены на квазибинарных разрезах $\mathrm{K}_{3} \mathrm{Na}\left(\mathrm{MoO}_{4}\right)_{2}-$ $\mathrm{AMoO}_{4}$. В структурах этих соединений позиции $M 1, M 2$ и $M 3$ заняты катионами $\mathrm{Na}^{+}, A^{2+}$ и $A^{2+}$, соответственно, а позиции калия, как и в предыдущем случае, заняты только наполовину. Данные по этим тройным молибдатам приведены в табл. 4. Изоструктурность рассматриваемых тройных молибдатов натрий-ионному проводнику II- $\mathrm{Na}_{3} \mathrm{Fe}_{2}\left(\mathrm{AsO}_{4}\right)_{3}$ дает основание ожидать наличия повышенной ионной проводимости. Предполагается, что пути транспорта ионов в этих фазах аналогичны обнаруженным в структуре II-Na $\mathrm{Fe}_{2}\left(\mathrm{AsO}_{4}\right)_{3}$, где катионы $\mathrm{Na}^{+}$ перемещаются через дефектные позиции натрия с КЧ = 9 и октаэдрическую позицию $M 1$, которые находятся в соседних координационных полиэдрах и образуют трехмерную сеть.

В системах $\mathrm{Li}_{2} \mathrm{MoO}_{4}-\mathrm{Rb}_{2} \mathrm{MoO}_{4}-$ $A \mathrm{MoO}_{4}(A=\mathrm{Mg}, \mathrm{Mn}, \mathrm{Co}, \mathrm{Ni})$ и $\mathrm{Li}_{2}-$ $\mathrm{MoO}_{4}-\mathrm{Cs}_{2} \mathrm{MoO}_{4}-\mathrm{AMoO}_{4}(A=\mathrm{Mg}, \mathrm{Mn}$, $\mathrm{Ni})$ тройные молибдаты не образуются. В системах с Rb и $\mathrm{Zn}$ (рис. 9, а) и цезийсодержащих системах с Со и $\mathrm{Zn}$ (рис. 9, б) найдены $\mathrm{Rb}_{3} \mathrm{LiZn}_{2}\left(\mathrm{MoO}_{4}\right)_{4}$ и $\mathrm{Cs}_{3} \mathrm{Li}_{2}\left(\mathrm{MoO}_{4}\right)_{4}(A=\mathrm{Co}, \mathrm{Zn})$ [4143], изоструктурные кубическому $\mathrm{Cs}_{6} \mathrm{Zn}_{5}\left(\mathrm{MoO}_{4}\right)_{8}[23,24]$. Уникальность состава и строения $\mathrm{Cs}_{6} \mathrm{Zn}_{5}\left(\mathrm{MoO}_{4}\right)_{8}$ связана с некомплектностью тетраэдрических позиций цинка, где их шестая часть вакантна. Заполнение вакансий ионами $\mathrm{Li}^{+}$и другими однозарядными катионами $M^{+}$по схеме $\mathrm{Zn}^{2+}+\square \rightarrow 2 M^{+}$ создает условия для получения новых соединений. Введением в структуру кубического $\mathrm{Cs}_{6} \mathrm{Zn}_{5}\left(\mathrm{MoO}_{4}\right)_{8}$ однозарядных катионов $M^{+}=\mathrm{Na}, \mathrm{Ag}$ с близкими к $\mathrm{Zn}^{2+}$ ионными радиусами получены кубические фазы $\mathrm{Cs}_{3} \mathrm{MZn}_{2}\left(\mathrm{MoO}_{4}\right)_{4}$ с неупорядоченным распределением катионов $M^{+}$по позициям $\mathrm{Zn}^{2+}$. Характеристики $\mathrm{Cs}_{3} M \mathrm{Zn}_{2}\left(\mathrm{MoO}_{4}\right)_{4}(M=\mathrm{Na}, \mathrm{Ag})$ приведены в табл. 4. По нашим данным [43, 50], между $\mathrm{Cs}_{3} \mathrm{MZn}_{2}\left(\mathrm{MoO}_{4}\right)_{4}$ $(M=\mathrm{Li}, \mathrm{Na})$ и $\mathrm{Cs}_{6} \mathrm{Zn}_{5}\left(\mathrm{MoO}_{4}\right)_{8}$ существуют непрерывные твердые растворы (рис. 9, б) с постепенным заполнением катионных вакансий в структуре $\mathrm{Cs}_{6} \mathrm{Zn}_{5}\left(\mathrm{MoO}_{4}\right)_{8}$. Вполне вероятно, что аналогичное явление имеет место и в случае $\mathrm{Cs}_{3} \mathrm{AgZn}_{2}\left(\mathrm{MoO}_{4}\right)_{4}$. Образование таких твердых растворов дает возможность в определенных пределах управлять составом, стабильностью и свойствами фаз на основе $\mathrm{Cs}_{6} \mathrm{Zn}_{5}\left(\mathrm{MoO}_{4}\right)_{8}$.

Нельзя не отметить, что замещение и одновременное внедрение в позиции цинка в структуре $\mathrm{Cs}_{6} \mathrm{Zn}_{5}\left(\mathrm{MoO}_{4}\right)_{8}$ разновалентных катионов с сильно различающимися ионными радиусами по схеме $5 \mathrm{Zn}^{2+}+\square \rightarrow 2 R^{3+}+4 \mathrm{Li}^{+}$ приводит к образованию группы тройных молибдатов $\mathrm{Li}_{2} M_{3} R\left(\mathrm{MoO}_{4}\right)_{4}$ $(M R=\mathrm{CsFe}, \mathrm{CsGa}, \mathrm{RbGa}, \mathrm{CsAl}, \mathrm{RbAl}$, TlAl), описанных выше. В последнем случае катионы $\mathrm{Li}^{+}$и $R^{3+}$ упорядоченно распределены в структуре, что приводит к тетрагональному искажению структуры прототипа.

Основу структур тройных молибдатов обеих серий, как и структуры $\mathrm{Cs}_{6} \mathrm{Zn}_{5}\left(\mathrm{MoO}_{4}\right)_{8}$, составляют ажурные трехмерные каркасы. В фазах с двухвалентными металлами они образованы тетраэдрами двух сортов - вокруг 
молибдена и «смешанной» позиции лития (натрия, серебра) и двухзарядного катиона; в соединениях с трехвалентными металлами - тетраэдрами $\mathrm{MoO}_{4}, \mathrm{LiO}_{4}$ и $R \mathrm{O}_{4}$. В больших пустотах каркаса размещаются крупные однозарядные катионы с КЧ = 12 (рис. 10).

Все фазы семейства $\mathrm{Cs}_{6} \mathrm{Zn}_{5}\left(\mathrm{MoO}_{4}\right)_{8}$ обладают ацентричным строением и перспективны для создания материалов нелинейной оптики. Кроме

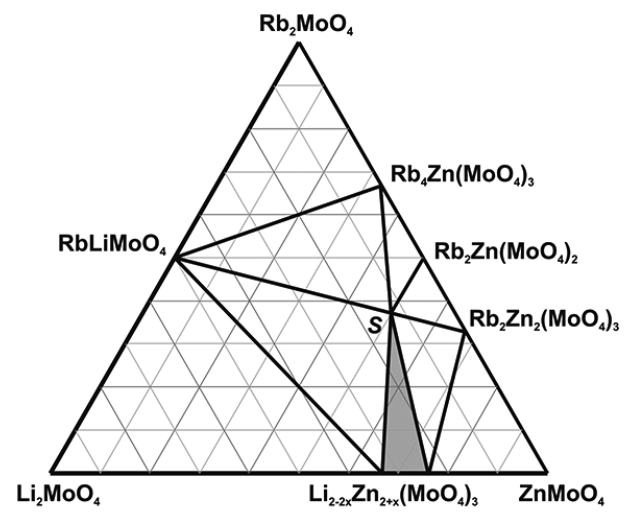

$a$ того, открытая каркасная структура обусловливает проявление этими соединениями ионопроводящих свойств. Наиболее значимые результаты получены для $\mathrm{Rb}_{3} \mathrm{LiZn}_{2}\left(\mathrm{MoO}_{4}\right)_{4}$ и $\mathrm{Tl}_{3} \mathrm{Li}_{2} \mathrm{Al}\left(\mathrm{MoO}_{4}\right)_{4}$, величины ионной проводимости которых (порядка $2 \cdot 10^{-2} \mathrm{Cm} /$ см при 520 и $350{ }^{\circ} \mathrm{C}$, соответственно), приближают их к суперионным проводникам.

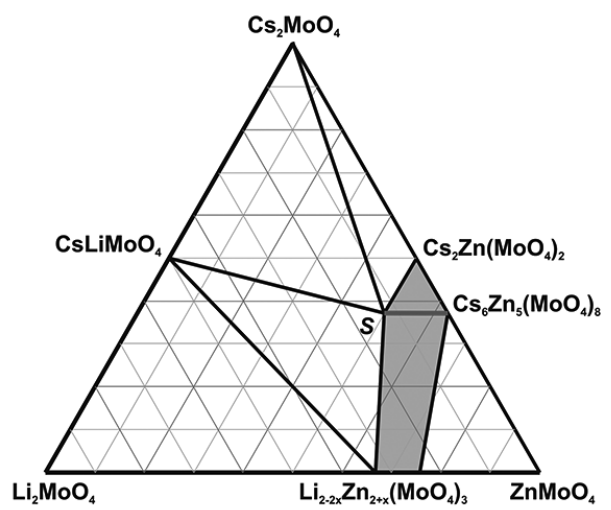

6

Рис. 9. Субсолидусная триангуляция тройных систем при $510{ }^{\circ} \mathrm{C}$ : $a-\mathrm{Li}_{2} \mathrm{MoO}_{4}-\mathrm{Rb}_{2} \mathrm{MoO}_{4}-\mathrm{ZnMoO}_{4} ; \sigma-\mathrm{Li}_{2} \mathrm{MoO}_{4}-\mathrm{Cs}_{2} \mathrm{MoO}_{4}-\mathrm{ZnMoO}_{4}$. $\mathrm{S}-\mathrm{M}_{3} \mathrm{LiZn}_{2}\left(\mathrm{MoO}_{4}\right)_{4}(\mathrm{M}=\mathrm{Rb}, \mathrm{Cs})$
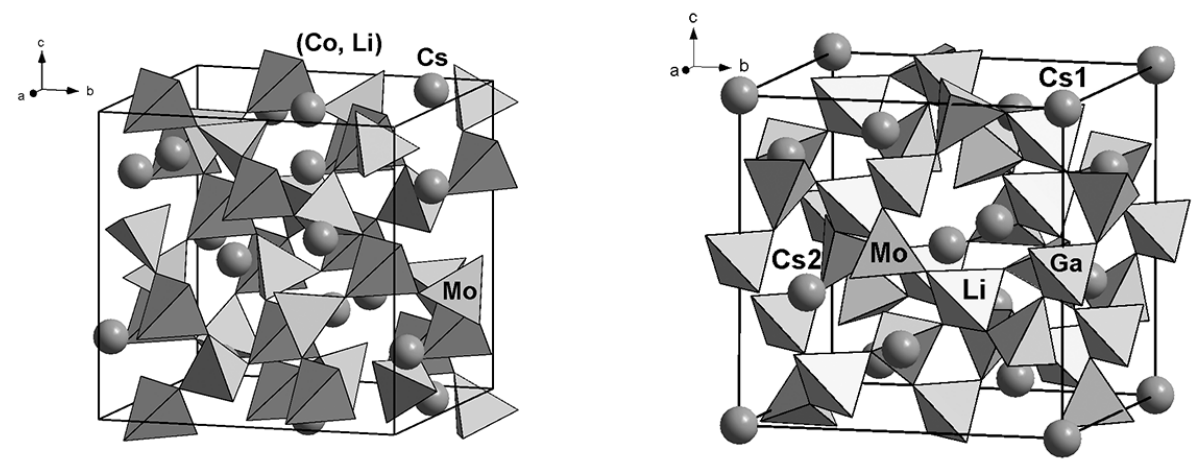

$a$

6

Рис. 10. Структуры тройных молибдатов, производных от структуры $\mathrm{Cs}_{6} \mathrm{Zn}_{5}\left(\mathrm{MoO}_{4}\right)_{8}$ $[23,24]: a$ - структура $\mathrm{LiCs}_{3} \mathrm{Co}_{2}\left(\mathrm{MoO}_{4}\right)_{4}$ (пр. гр. I 43d) [41];

6 - структура $\mathrm{Li}_{2} \mathrm{Cs}_{3} \mathrm{Ga}\left(\mathrm{MoO}_{4}\right)_{4}$ (пр. гр. I $\left.\overline{4} 2 \mathrm{~d}\right)[42]$ 
В системах $\mathrm{Li}_{2} \mathrm{MoO}_{4}-\mathrm{M}_{2} \mathrm{MoO}_{4}-$ $\mathrm{AMoO}_{4}(M=\mathrm{Na}, \mathrm{K}, \mathrm{Rb}, \mathrm{Cs} ; A=\mathrm{Ca}, \mathrm{Sr}$, $\mathrm{Pb}, \mathrm{Ba}, \mathrm{Cd})$ тройные молибдаты не образуются, однако имеются области твердых растворов (до 15 мол. \%) на основе двойных молибдатов из ограняющих систем $M_{2} \mathrm{MoO}_{4}-\mathrm{AMoO}_{4}$ [51].

При исследовании раствор-расплавной кристаллизации (растворитель - $\mathrm{Cs}_{2} \mathrm{Mo}_{2} \mathrm{O}_{7}$ ) в системах $\mathrm{Na}_{2} \mathrm{MoO}_{4}-$ $\mathrm{Cs}_{2} \mathrm{MoO}_{4}-\mathrm{AMoO}_{4}(A=\mathrm{Ni}, \mathrm{Co}, \mathrm{Mn})$ выделены и структурно изучены кристаллы $\mathrm{CsNa}_{5} \mathrm{M}_{3}\left(\mathrm{MoO}_{4}\right)_{6}$ [47], относящиеся к типу аллюодита. Кислородные октаэдры вокруг катионов $A^{2+}$ и $\mathrm{Na}^{+}$соединяются между собой общими ребрами и гранями, а далее по общим вершинам с тетраэдрами $\mathrm{MoO}_{4}$ в трехмерный каркас, который параллельно (100) разбивается на два вида слоев (рис. 11). В одном из таких слоев (рис. 11, в) параллельно оси $c$ проходят широкие сквозные каналы, заполненные ионами цезия, которые занимают свои позиции наполовину и имеют КЧ = 8. Сравнение аллюодитоподобных структур $\mathrm{CsNa}_{5} A_{3}\left(\mathrm{MoO}_{4}\right)_{6}$ и $\mathrm{Na}_{4-2 x} A_{1+x}\left(\mathrm{MoO}_{4}\right)_{3}(A=\mathrm{Ni}, \mathrm{Co}, \mathrm{Mn})$ по- казывает, что в тройных молибдатах часть катионов $\mathrm{Na}^{+}$в каналах замещена $\mathrm{Cs}^{+}$, существенно увеличены параметры ячеек вдоль оси $a$ и, соответственно, ширина каналов. Так как вдоль этих каналов может осуществляться транспорт ионов натрия, это может способствовать увеличению ионной проводимости. Близкое родство фаз $\mathrm{CsNa}_{5} A_{3}\left(\mathrm{MoO}_{4}\right)_{6}$ и $\mathrm{Na}_{4-2 x} A_{1+x}\left(\mathrm{MoO}_{4}\right)_{3}$ $(A=\mathrm{Ni}, \mathrm{Co}, \mathrm{Mn})$ может означать образование между ними твердых растворов, что требует дополнительного исследования. Характеристики $\mathrm{CsNa}_{5} A_{3}\left(\mathrm{MoO}_{4}\right)_{6}(A=\mathrm{Ni}, \mathrm{Co}, \mathrm{Mn})$ приведены в табл. 4.

В системах $\mathrm{Na}_{2} \mathrm{MoO}_{4}-\mathrm{Cs}_{2} \mathrm{MoO}_{4}$ $A \mathrm{MoO}_{4}(A=\mathrm{Co}, \mathrm{Mn})$ также выделены тройные молибдаты состава $\mathrm{Cs}_{4} \mathrm{Na}_{10} A_{5}\left(\mathrm{MoO}_{4}\right)_{12} \quad[46,48] \quad$ (рис. 12, табл. 4), которые оказались очень близки по строению с вышеописанными соединениями $\mathrm{Na}_{25} \mathrm{Cs}_{8} R_{5}\left(\mathrm{MoO}_{4}\right)_{24}$ ( $R=\mathrm{In}, \mathrm{Sc}, \mathrm{Fe})$, образуя вместе с ними, очевидно, единое семейство фаз с близкими метриками ячеек и разной симметрией. Наиболее симметрична структура $\mathrm{Cs}_{4} \mathrm{Na}_{10} \mathrm{Co}_{5}\left(\mathrm{MoO}_{4}\right)_{12}$ (пр. гр.

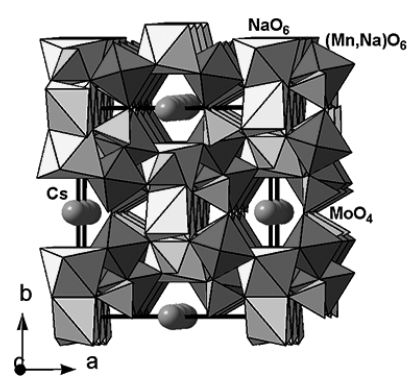

$a$

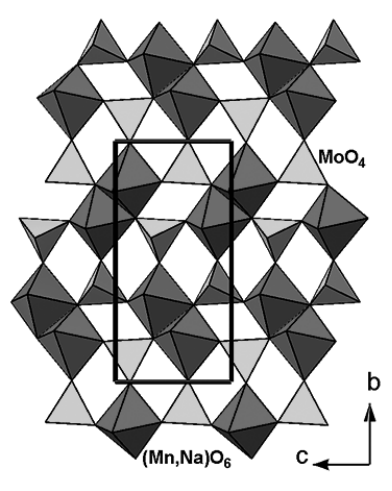

6

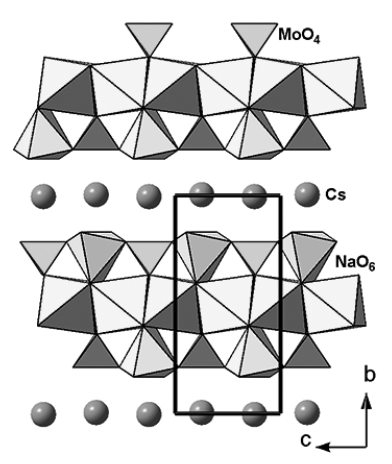

B

Рис. 11. Структура $\mathrm{CsNa}_{5} \mathrm{Mn}_{3}\left(\mathrm{MoO}_{4}\right)_{6}$ : $a$ - общий вид; 6, в - два вида слоев полиэдров в проекции на (100) 
Pbca), которую можно считать родоначальником данного семейства. Симметрия остальных соединений может повышаться при фазовых переходах, что должно сопровождаться разупорядочением структуры и возможным ростом подвижности катионов натрия.

В связи с этим можно ожидать у тройных молибдатов $\mathrm{Cs}_{4} \mathrm{Na}_{10} A_{5}\left(\mathrm{MoO}_{4}\right)_{12}$ $(A=\mathrm{Co}, \mathrm{Mn})$ повышенной ионной проводимости, как это имеет место для $\mathrm{Na}_{25} \mathrm{Cs}_{8} R_{5}\left(\mathrm{MoO}_{4}\right)_{24}(R=\mathrm{In}, \mathrm{Sc}, \mathrm{Fe})$.

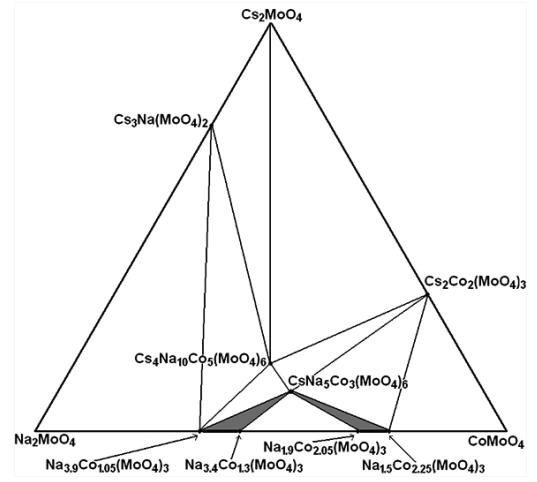

Рис. 12. Субсолидусная триангуляция системы $\mathrm{Na}_{2} \mathrm{MoO}_{4}-\mathrm{Cs}_{2} \mathrm{MoO}_{4}-\mathrm{CoMoO}_{4}$ при $480^{\circ} \mathrm{C}$

\section{Заключительные замечания}

Проведенные нами исследования тройных молибдатов типа 1-1-3 и 1-1-2 показывают, что среди них имеются несколько семейств изоструктурных или близко родственных по строению фаз. Более высокой фазообразующей способностью, большим стехиометрическим и структурным разнообразием обладают системы с трехвалентными металлами, в которых формируются тройные молибдаты, принадлежащие к 14 структурным типам (семействам), тогда как тройные молибдаты типа 1-1-2 относятся только к четырем изоструктурным рядам. Одним из объяснений этого может быть более широкий спектр катионов $R^{3+}$ и их размеров по сравнению с ионами $A^{2+}$ в фазообразующих системах $\mathrm{M}_{2} \mathrm{MoO}_{4}$ $M^{\prime \prime}{ }_{2} \mathrm{MoO}_{4}-\mathrm{AMoO}_{4} \quad\left(M^{\prime}=\mathrm{Li}, \quad \mathrm{Na}\right.$; $M "=\mathrm{K}, \mathrm{Rb}, \mathrm{Cs} ; A=\mathrm{Mg}, \mathrm{Mn}, \mathrm{Co}, \mathrm{Ni}$, $\mathrm{Zn).} \mathrm{Ряд} \mathrm{выявленных} \mathrm{семейств} \mathrm{трой-}$ ных молибдатов типов 1-1-3 и 1-1-2 могут быть перспективными в качестве функциональных материалов. Это прежде всего относится к се- мейству соединений $\mathrm{LiMR}\left(\mathrm{MoO}_{4}\right)_{4}$ c интересными спектрально-люминесцентными свойствами, а также литий- и натрий-содержащим тройным молибдатам различного строения, которые могут проявлять повышенную ионную проводимость. Среди последних можно выделить соединения семейств $\mathrm{Cs}_{6} \mathrm{Zn}_{5}\left(\mathrm{MoO}_{4}\right)_{8}$, $\mathrm{II}-\mathrm{Na}_{3} \mathrm{Fe}_{2}\left(\mathrm{AsO}_{4}\right)_{3}$ и аллюодитоподобные фазы $\mathrm{Na}_{25} \mathrm{Cs}_{8} R_{5}\left(\mathrm{MoO}_{4}\right)_{24}(R=\mathrm{In}, \mathrm{Sc}$, $\mathrm{Fe})$ и $\mathrm{Cs}_{4} \mathrm{Na}_{10} M_{5}\left(\mathrm{MoO}_{4}\right)_{12}(M=\mathrm{Co}, \mathrm{Mn})$, для которых уже проведены соответствующие исследования. С кристаллохимической точки зрения в этом плане также интересны соединения $\mathrm{Li} M R_{2}\left(\mathrm{MoO}_{4}\right)_{4}$, где ионы $\mathrm{Li}^{+}$заполняют междоузельные пустоты структурного типа $\mathrm{BaNd}_{2}\left(\mathrm{MoO}_{4}\right)_{4}$, а также гексагональные или тригональные фазы $S_{1}-S_{4}$ (табл. 2,3 ), в которых ионы натрия обладают нестандартной (тригонально-призматической или более низкой) координацией, что может способствовать ионной проводимости. Нелинейно-оптические свойст- 
ва можно ожидать у ацентричных тройных молибдатов $\mathrm{LiK}_{2} \mathrm{In}\left(\mathrm{MoO}_{4}\right)_{3}$, $\mathrm{LiCs}_{4} \mathrm{Al}\left(\mathrm{MoO}_{4}\right), \quad \mathrm{Na}_{5} \mathrm{Cs}_{7} \mathrm{Yb}_{2}\left(\mathrm{MoO}_{4}\right)_{9}$,
$\mathrm{NaCs}_{2} \mathrm{Bi}\left(\mathrm{MoO}_{4}\right)_{3}$ и их аналогов, а также фаз семейства $\mathrm{Cs}_{6} \mathrm{Zn}_{5}\left(\mathrm{MoO}_{4}\right)_{8}$.

1. Трунов В. К., Ефремов В. А., Великодный Ю. А. Кристаллохимия и свойства двойных молибдатов и вольфраматов. Л.: Наука, 1986, 173 с.

2. Евдокимов А. А., Ефремов В. А., Трунов В. К., Клейман И. А., Тананаев И. В. Соединения редкоземельных элементов. Молибдаты, вольфраматы. М.: Наука, 1991, 267 с.

3. Каминский А. А., Аминов Л. К., Ермолаев В. Л., Корниенко А. А., Кравченко Е. Б., Малкин Б. 3., Милль Б. В., Перлин Ю. Е., Петросян А. Г., Пехов К. К., Сакун В. П., Саркисов С. Э., Свешникова Е. Б., Скрипко Г. А., Старостин Н. В. Шкадаревич А. П. Физика и спектроскопия лазерных кристаллов. М.: Наука, 1986,272 c.

4. Isupov V. A. Binary molybdates and tungstates of mono- and trivalent elements as possible ferroelastics and ferroelectrics. Ferroelectrics. 2005;321:63-90. doi: 10.1080/00150190500259699.

5. Isupov V. A. Ferroelectric and ferroelastic phase transitions in molybdates and tungstates of monovalent and bivalent elements. Ferroelectrics. 2005;322:83-114. doi: 10.1080/00150190500315574

6. Хайкина Е. Г., Базарова Ж. Г., Солодовников С. Ф., Клевцова Р. Ф. Тройные молибдаты как основа новых перспективных сложнооксидных материалов. Инженерная экология. 2011;1:48-49.

7. Basovich O. M., Khaikina E. G., Solodovnikov S. F., Tsyrenova G. D. Phase formation in the systems $\mathrm{Li}_{2} \mathrm{MoO}_{4}-\mathrm{K}_{2} \mathrm{MoO}_{4}-\mathrm{Ln}_{2}\left(\mathrm{MoO}_{4}\right)_{3}(\mathrm{Ln}=\mathrm{La}, \mathrm{Nd}, \mathrm{Dy}, \mathrm{Er})$ and properties of triple molybdates $\mathrm{LiKLn}_{2}\left(\mathrm{MoO}_{4}\right)_{4}$. J. Solid State Chem. 2005;178(5):15801588. doi: 10.1016/j.jssc.2004.12.016.

8. Басович О. М., Хайкина Е. Г., Васильев Е. В., Фролов А. М. Фазообразование в системах $\mathrm{Li}_{2} \mathrm{MoO}_{4}-\mathrm{Rb}_{2} \mathrm{MoO}_{4}-\operatorname{Ln}_{2}\left(\mathrm{MoO}_{4}\right)_{3}$ и свойства LiRbLn ${ }_{2}\left(\mathrm{MoO}_{4}\right)_{4}$. Жypнал неорган. химии. 1995;40(12):2047-2051.

9. Басович О. М., Хайкина Е. Г. Фазовые равновесия в системе $\mathrm{Li}_{2} \mathrm{MoO}_{4}-\mathrm{Tl}_{2}-$ $\mathrm{MoO}_{4}-\mathrm{Pr}_{2}\left(\mathrm{MoO}_{4}\right)_{3}$. Журнал неорган. химии. 2000;45(9):1542-1544.

10. Кадырова Ю. М. Фазообразование, синтез и строение новых соединений в системах $M_{2} \mathrm{MoO}_{4}-R_{2}\left(\mathrm{MoO}_{4}\right)_{3}$ и $\mathrm{Li}_{2} \mathrm{MoO}_{4}-M_{2} \mathrm{MoO}_{4}-R_{2}\left(\mathrm{MoO}_{4}\right)_{3}(M-$ щелочной металл; $R=\mathrm{In}, \mathrm{Sc}, \mathrm{Fe}, \mathrm{Ga}, \mathrm{Cr}, \mathrm{Al})$ : дис. ... канд. хим. наук. Улан-Удэ, 2010. 148 с.

11. Басович O. М., Хайкина Е. Г. Закономерности образования шеелитоподобных тройных молибдатов LiMLn $2\left(\mathrm{MoO}_{4}\right)$. Журнал неорган. химии. 2006;51(7):11801184. doi: 10.1134/S0036023606070114.

12. Szillat H., Müller-Buschbaum H. Synthese und Kristallstruktur von $\mathrm{KCuHoMo}_{4} \mathrm{O}_{16}$ Z. Naturforsch. 1994;49:350-354.

13. Müller-Buschbaum H., Gallinat St. Synthese und Röntgenstrukturanalyse von $\mathrm{KCuGd}_{2} \mathrm{Mo}_{4} \mathrm{O}_{16}$ und $\mathrm{KCuTb}_{2} \mathrm{Mo}_{4} \mathrm{O}_{16}$. Z. Naturforsch. 1995;50:1794-1798.

14. Клевцова Р. Ф., Глинская Л. А., Алексеев В. И., Хальбаева К. М., Хайкина Е. Г. 
Кристаллоструктурное исследование тройного молибдата $\mathrm{LiRbBi}_{2}\left(\mathrm{MoO}_{4}\right)_{4}$. Журнал структур. химии. 1993;34(5):152-156.

15. Хальбаева К. М., Хайкина Е. Г. Субсолидусное строение системы $\mathrm{Li}_{2} \mathrm{MoO}_{4}-$ $\mathrm{Tl}_{2}-\mathrm{MoO}_{4}-\mathrm{Bi}_{2}\left(\mathrm{MoO}_{4}\right)_{3}$. Журнал неорган. химии. 2000;45(2):314-319.

16. Морозов В. А., Лазоряк Б. И., Смирнов В. А., Михайлин В. В., Басович О. М., Хайкина Е. Г. Кристаллические структуры и люминесцентные свойства тройных молибдатов $\mathrm{Li} M \mathrm{Nd}_{2}\left(\mathrm{MoO}_{4}\right)_{4}(M=\mathrm{K}, \mathrm{Rb}, \mathrm{Tl})$. Журнал неорган. химии. 2001;46(6):977-982.

17. Клевцова Р. Ф., Васильев А. Д., Глинская Л. А., Круглик А. И., Кожевникова Н. М., Корсун В. П. Кристаллоструктурное исследование тройных молибдатов состава $\mathrm{Li}_{3} \mathrm{Ba}_{2} \operatorname{Ln}_{3}\left(\mathrm{MoO}_{4}\right)_{8}, \mathrm{Ln}=\mathrm{Gd}, \mathrm{Tm}$. Журнал структур. химии. 1992;33(3):126-130.

18. Киселева И. И., Сирота М. И., Озеров Р. И., Балакирева Т. П. Майер А. А. Двойные молибдаты барий-лантаноидов, $\mathrm{BaLn} 2\left(\mathrm{MoO}_{4}\right)_{4}$. Кристаллография. 1979;24(6):1277-1279.

19. Bravina S., Morozovsky N., Pasechnik L., Khaikina E., Budnyk O. Characteristic behaviour of electric parameters of mesoporous materials under humidity impact, $9^{\text {th }}$ Eur. Conf. on Applications of Polar Dielectrics ECAPD-9. Abstract. Roma, Italy, 2008. P. 208.

20. Bravina S. L., Morozovsky N. V., Khaikina E. G., Boukherroub R., Dogheche E., Remiens D., Basovich O. M., Kadyrova Yu. M. Electrophysical study of fast humidity sensing of nano- and mesoporous media / Материалы Всерос. науч. конф. с междунар. участием «Байкальский материаловедческий форум». 9-13 июля 2012 г., г. Улан-Удэ. Улан-Удэ: Изд-во БНЦ СО РАН, 2012. Ч. 2. С. 23-25.

21. Яковлев В. Г., Михайлин В. В., Романенко А. Ю., Заушицын А. В., Басович О. М., Хайкина Е. Г. Спектрально-люминесцентные свойства $\operatorname{LiRbLa}_{2-x} \mathrm{Eu}_{x}\left(\mathrm{MoO}_{4}\right)_{4}$. Вестник МГУ. Сер. 3. Физика. Астрономия. 2010;(5):56-59.

22. Xie A., Yuan X. M., Wang F. X. A potential red-emitting phosphors scheelite-like triple molybdates $\mathrm{LiKGd}_{2}\left(\mathrm{MoO}_{4}\right)_{4}: \mathrm{Eu}^{3+}$ for white light emitting diode applications. Sci. China. Tech. Sci. 2011;54(1):70-75. doi: 10.1007/s11431-010-4222-y.

23. Mueller M., Hildmann B. O., Hahn Th. Structure of $\mathrm{Cs}_{6} \mathrm{Zn}_{5}\left(\mathrm{MoO}_{4}\right)_{8}$. Acta crystallogr. 1987:C43(2):184-186.

24. Солодовников С. Ф., Клевцов П. В., Глинская Л. А., Клевцова Р. Ф. Синтез и кристаллическая структура цезий-цинкового молибдата $\mathrm{Cs}_{6} \mathrm{Zn}_{5}\left(\mathrm{MoO}_{4}\right)_{8}=$ $2 \mathrm{Cs}_{3}\left(\mathrm{Zn}_{5 / 6} \square_{1 / 6}\right)_{3}\left(\mathrm{MoO}_{4}\right)_{4}$. Кристаллография. 1987;32(3):618-622.

25. Khal'baeva K. M., Solodovnikov S. F., Khaikina E. G., Kadyrova Yu. M., Solodovnikova $\mathrm{Z}$. A., Basovich O. M. Phase formation in the $\mathrm{Li}_{2} \mathrm{MoO}_{4}-\mathrm{K}_{2} \mathrm{MoO}_{4}-\mathrm{In}_{2}\left(\mathrm{MoO}_{4}\right)_{3}$ system and crystal structures of new compounds $\mathrm{K}_{3} \mathrm{InMo}_{4} \mathrm{O}_{15}$ and $\mathrm{LiK}_{2} \mathrm{In}\left(\mathrm{MoO}_{4}\right)_{3}$. J. Solid State Chem. 2012;87:276-281. doi: 10.1016/j.jssc.2012.01.010.

26. Khal'baeva K. M., Solodovnikov S. F., Khaikina E. G., Kadyrova Yu. M., Solodovnikova Z. A., Basovich O. M. Phase formation in the $\mathrm{Li}_{2} \mathrm{MoO}_{4}-\mathrm{Rb}_{2} \mathrm{MoO}_{4}-\mathrm{Fe}_{2}\left(\mathrm{MoO}_{4}\right)_{3}$ system and crystal structure of a novel triple molybdate $\mathrm{LiRb}_{2} \mathrm{Fe}\left(\mathrm{MoO}_{4}\right)_{3}$. J. Solid State Chem. 2013;203:227-231. doi: 10.1016/jjssc.2013.04.020. 
27. Солодовников С. Ф., Солодовникова 3. А., Кадырова Ю. М., Хайкина Е. Г., Басович О. М. Фазообразование в системе $\mathrm{Li}_{2} \mathrm{MoO}_{4}-\mathrm{Cs}_{2} \mathrm{MoO}_{4}-\mathrm{Al}_{2}\left(\mathrm{MoO}_{4}\right)_{3}$ и кристаллическая структура $\mathrm{LiCs}_{4} \mathrm{Al}\left(\mathrm{MoO}_{4}\right)_{4} / /$ Матер. Всерос. науч. конф. с междунар. участием «Байкальский материаловедческий форум». 9-13 июля 2012 г., г. Улан-Удэ. Улан-Удэ: Изд-во БНЦ СО РАН, 2012. Ч. 2. С. 141-142.

28. Хайкина Е. Г., Басович О. М., Хальбаева К. М. Фазообразование в серебросодержащих молибдатных системах с участием трехвалентных металлов // III Всерос. науч. конф. по физико-химическому анализу. Махачкала, 12-14 апреля 2007 г. / Тезисы докл. Махачкала, 2007. С. 39-41.

29. Хальбаева К. М., Хайкина Е. Г., Басович О. М. Фазовые равновесия в молибдатных системах лития-серебра(натрия)-висмута. Журн. неорган. химии. 2005;50(8):1380-1382.

30. Хайкина Е. Г. Синтез, особенности фазообразования и строения двойных и тройных молибдатов одно- и трехвалентных металлов : дис. ... д-ра хим. наук. Улан-Удэ, 2008. 446 с.

31. Савина А. А. Синтез, строение и свойства новых соединений в системах $\mathrm{Na}_{2} \mathrm{MoO}_{4}-\mathrm{Cs}_{2} \mathrm{MoO}_{4}-R_{2}\left(\mathrm{MoO}_{4}\right)_{3}(R-$ трехвалентный металл) : дис. ... канд. хим. наук. Улан-Удэ, 2013. 169 с.

32. Басович О. М., Осокина А. Н., Хайкина Е. Г., Солодовников С. Ф., Спиридонова Т. С., Солодовникова 3. А. Фазообразование в системах $\mathrm{Ag}_{2} \mathrm{MoO}_{4}-$ $\mathrm{Cs}_{2}-\mathrm{MoO}_{4}-R_{2}\left(\mathrm{MoO}_{4}\right)_{3}(R=\mathrm{Bi}, \mathrm{Nd}, \mathrm{Yb}, \mathrm{Lu}, \mathrm{In}, \mathrm{Sc}) /$ Тезисы докл. Школы-конференции молодых ученых «Неорганические соединения и функциональные материалы (ICFM-2015)». Новосибирск: Изд-во ИНХ СО РАН, 2015. С. 81.

33. Солодовников С. Ф. Особенности фазообразования и кристаллохимии двойных молибдатов и вольфраматов щелочных и двухвалентных металлов и сопутствующих им фаз : дис. ... д-ра хим. наук. Новосибирск: 2000. 424 с.

34. Кожевникова Н. М., Мохосоев М. В. Тройные молибдаты. Улан-Удэ: Изд-во Бурят. гос. ун-та, 2000. 297 с.

35. Ускова А. А., Басович О.М., Солодовников С.Ф., Подкорытова Ю.О., Солодовникова 3.А., Хайкина Е.Г. Поиск и исследование тройных натрийсодержащих молибдатов с цезием и трехвалентными металлами : материалы Всерос. молодеж. науч.-практ. конф. с междунар. участием «Экологобезопасные и ресурсосберегающие технологии и материалы». 12-14 мая 2011 г., г. Улан-Удэ. Улан-Удэ: Изд-во БГУ, 2011. С. 57-59.

36. Басович О. М., Ускова А. А., Солодовников С. Ф., Солодовникова 3. А., Хайкина Е. Г. Фазообразование в системах $\mathrm{Na}_{2} \mathrm{MoO}_{4}-\mathrm{Cs}_{2} \mathrm{MoO}_{4}-\mathrm{Ln}_{2}\left(\mathrm{MoO}_{4}\right)_{3}$ и кристаллическая структура нового тройного молибдата $\mathrm{Cs}_{7} \mathrm{Na}_{5} \mathrm{Yb}_{2}\left(\mathrm{MoO}_{4}\right)_{9}$. Вестн. Бурят. гос. ун-та. Вьп. 3. Химия, физика. 2011;24-29.

37. Savina A. A., Atuchin V. V., Solodovnikov S. F., Solodovnikova Z. A., Krylov A. S., Maximovskiy E. A., Molokeev M. S., Oreshonkov A. S., Pugachev A. M., Khaikina E. G. Synthesis, structural and spectroscopic properties of acentric triple molybdate $\mathrm{Cs}_{2} \mathrm{NaBi}\left(\mathrm{MoO}_{4}\right)_{3}$. J. Solid State Chem. 2015;225:53-58. doi: 10.1016/j. jssc.2014.11.023. 
38. Савина А. А., Солодовников С. Ф., Белов Д. А., Басович О. М., Солодовникова 3. А., Гудкова И. А., Стефанович С. Ю., Лазоряк Б. И., Хайкина Е. Г. Новые ионопроводящие тройные молибдаты с аллюодитоподобной структурой, «Экологобезопасные и ресурсосберегающие технологии и материалы» : материалы II Всерос. молод. науч. конф. с междунар. участием (Улан-Удэ, 1516 мая 2014 г.). Улан-Удэ: Изд-во Бурятского госуниверситета, 2014. С. 93-94.

39. Savina A. A., Solodovnikov S. F., Belov D. A., Basovich O. M., Solodovnikova Z. A., Pokholok K. V., Stefanovich S. Yu., Lazoryak B. I., Khaikina E. G. Synthesis, crystal structure and properties of alluaudite-like triple molybdate $\mathrm{Na}_{25} \mathrm{Cs}_{8} \mathrm{Fe}_{5}\left(\mathrm{MoO}_{4}\right)_{24}$. J. Solid State Chem. 2014;220:217-220. doi: 10.1016/j.ssc.2014.09.004.

40. Moore P. B. Crystal chemistry of the alluaudite structure type: contribution to the paragenesis of pegmatite phosphate giant crystals. Amer. Miner. 1971;56(1112):1955.

41. Solodovnikova Z. A., Solodovnikov S. F., Zolotova E. S. New triple molybdates $\mathrm{Cs}_{3} \mathrm{LiCo}_{2}\left(\mathrm{MoO}_{4}\right)_{4}$ and $\mathrm{Rb}_{3} \mathrm{LiZn}_{2}\left(\mathrm{MoO}_{4}\right)_{4}$, filled derivatives of the $\mathrm{Cs}_{6} \mathrm{Zn}_{5}\left(\mathrm{MoO}_{4}\right)_{8}$ type. Acta crystallogr. 2006;C62(1):i6-i8. doi: 10.1107/S0108270105037121.

42. Солодовников С. Ф., Хайкина Е. Г., Солодовникова З. А., Кадырова Ю. М., Хальбаева К. М., Золотова Е. С. Новые семейства литийсодержащих тройных молибдатов и стабилизирующая роль лития в их структурообразовании. Доклады РАН. 2007;416(1):60-65.

43. Солодовникова 3. А. Фазообразование и строение тройных молибдатов и сопутствующих соединений в системах $\mathrm{Li}_{2} \mathrm{MoO}_{4}-A^{+}{ }_{2} \mathrm{MoO}_{4}-M^{2+} \mathrm{MoO}_{4}\left(A^{+}=\mathrm{K}\right.$, $\left.\mathrm{Rb}, \mathrm{Cs} ; M^{2+}=\mathrm{Mg}, \mathrm{Mn}, \mathrm{Co}, \mathrm{Ni}, \mathrm{Zn}\right)$ : дис. ... канд. хим. наук. Новосибирск, 2008. 219 c.

44. Солодовникова 3. А., Солодовников С. Ф., Гудкова И. А., Золотова Е. С. Синтез и строение новых тройных молибдатов $\mathrm{K}_{3} \mathrm{NaM}_{4}\left(\mathrm{MoO}_{4}\right)_{6}(M=\mathrm{Ni}, \mathrm{Mg}, \mathrm{Co})$ : материалы Всерос. науч. конф. с междунар. участием «Байкальский материаловедческий форум». 9-13 июля 2012 г., г. Улан-Удэ. Улан-Удэ: Изд-во БНЦ СО РАН, 2012. Ч. 2. С. 143-144.

45. Солодовников С. Ф., Солодовникова 3. А., Золотова Е. С., Юдин В. Н., Гудкова И. А., Кадырова Ю. М., Хайкина Е. Г. Тройные молибдаты (вольфраматы) семейства $\mathrm{Cs}_{6} \mathrm{Zn}_{5}\left(\mathrm{MoO}_{4}\right)_{8} / /$ Тез. докл. 9-го семинара СО РАН - УрО РАН «Термодинамика и материаловедение», посвящ. памяти акад. Ф. А. Кузнецова. 30 июня - 4 июля 2014 г., г. Новосибирск. Новосибирск: Изд-во ИНХ СО РАН, 2014. C. 108.

46. Юдин В. Н., Золотова Е. С., Солодовникова 3. А., Солодовников С. Ф., Гудкова И. А. Фазообразование и строение тройных молибдатов в системе $\mathrm{Cs}_{2} \mathrm{MoO}_{4}-$ $\mathrm{Na}_{2} \mathrm{MoO}_{4}-\mathrm{MnMoO}_{4} / /$ Тез. докл. 9-го семинара СО РАН - УрО РАН «Термодинамика и материаловедение», посвящ. памяти акад. Ф. А. Кузнецова. 30 июня 4 июля 2014 г., г. Новосибирск. Новосибирск: Изд-во ИНХ СО РАН, 2014. C. 151 .

47. Юдин В. Н., Золотова Е. С., Шкерин С. Н., Толкачева А. С., Упоров С. А., Солодовникова 3. А., Солодовников С. Ф. Строение и свойства тройных молибда- 
тов $\mathrm{CsNa}_{5} M_{3}\left(\mathrm{MoO}_{4}\right)_{6}(M=\mathrm{Ni}, \mathrm{Co}, \mathrm{Mn}) / /$ Материалы Всерос. науч. конф. с междунар. участием «II Байкальский материаловедческий форум». 29 июня - 5 июля 2015 г., г. Улан-Удэ. Улан-Удэ: Изд-во БНЦ СО РАН, 2015. Ч. 1. С. 146148.

48. Юдин В. Н., Золотова Е. С., Солодовникова З. А., Солодовников С. Ф., Толкачева А. С. Фазообразование, строение и свойства тройных молибдатов в системе $\mathrm{Cs}_{2} \mathrm{MoO}_{4}-\mathrm{Na}_{2} \mathrm{MoO}_{4}-\mathrm{CoMoO}_{4}$ // Тез. докл. Школы-конференции молодых ученых «Неорганические соединения и функциональные материалы (ICFM-2015)». Новосибирск: Изд-во ИНХ СО РАН, 2015. С. 139.

49. D’Yvoire F., Bretey E., Collin G. Crystal structure, non-stoichiometry and conductivity of II- $\mathrm{Na}_{3} M_{2}\left(\mathrm{AsO}_{4}\right)_{3}(M=\mathrm{Al}, \mathrm{Ga}, \mathrm{Cr}, \mathrm{Fe})$. Solid State Ionics. 1988;28-30:12591264. doi: 10.1016/0167-2738(88)90367-0.

50. Zolotova E. S., Solodovnikova Z. A., Yudin V. N., Solodovnikov S. F., Khaikina E. G., Basovich O. M., Korolkov I. V., Filatova I. Yu. Phase relations in the $\mathrm{Na}_{2} \mathrm{MoO}_{4}-\mathrm{Cs}_{2} \mathrm{MoO}_{4}$ and $\mathrm{Na}_{2} \mathrm{MoO}_{4}-\mathrm{Cs}_{2} \mathrm{MoO}_{4}-\mathrm{ZnMoO}_{4}$ systems, crystal structures of $\mathrm{Cs}_{3} \mathrm{Na}\left(\mathrm{MoO}_{4}\right)_{2}$ and $\mathrm{Cs}_{3} \mathrm{NaZn}_{2}\left(\mathrm{MoO}_{4}\right)_{4}$. J. Solid State Chem. 2015 (принята в печать).

51. Гудкова И. А. Фазовые равновесия, синтез, строение и свойства соединений, образующихся в тройных системах $\mathrm{Li}_{2} \mathrm{MoO}_{4}-A_{2} \mathrm{MoO}_{4}-\mathrm{MMoO}_{4}(A=\mathrm{Na}, \mathrm{K}, \mathrm{Rb}$, $\mathrm{Cs} ; M=\mathrm{Ca}, \mathrm{Sr}, \mathrm{Pb}, \mathrm{Ba}, \mathrm{Cd})$ : дис. ... канд. хим. наук. Новосибирск, 2014. 192 с. 